\title{
Hydrologic calibration of paired watersheds using a MOSUM approach
}

H. Ssegane ${ }^{1}$, D. M. Amatya ${ }^{2}$, A. Muwamba ${ }^{3}$, G. M. Chescheir ${ }^{4}$, T. Appelboom ${ }^{4}$, E. W. Tollner ${ }^{3}$, J. E. Nettles ${ }^{5}$, M. A. Youssef ${ }^{4}$, F. Birgand ${ }^{4}$, and R. W. Skaggs ${ }^{4}$

${ }^{1}$ Energy Systems Division, Argonne National Laboratory, Lemont, IL, USA

${ }^{2}$ Center for Forested Wetlands Research, USDA-FS, Cordesville, SC, USA

${ }^{3}$ University of Georgia, Athens, GA, USA

${ }^{4}$ North Carolina State University, Raleigh, NC, USA

${ }^{5}$ Weyerhaeuser Company, Columbus, MS, USA

Received: 29 November 2014 - Accepted: 3 December 2014 - Published: 9 January 2015

Correspondence to: H. Ssegane (hssegane@anl.gov)

Published by Copernicus Publications on behalf of the European Geosciences Union.
Hydrologic

calibration of paired watersheds using

a MOSUM approach

H. Ssegane et al.

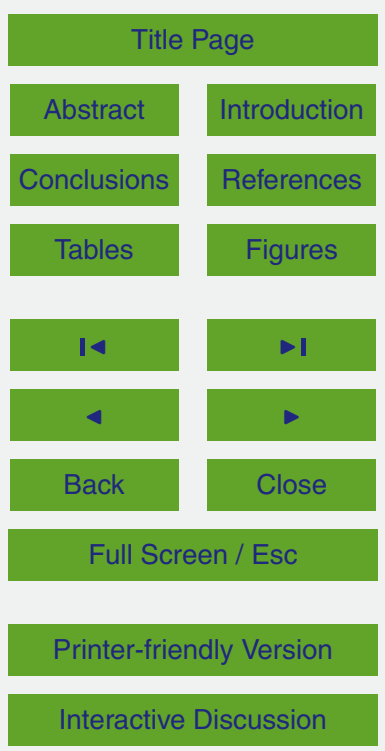




\section{Abstract}

Paired watershed studies have historically been used to quantify hydrologic effects of land use and management practices by concurrently monitoring two neighboring watersheds (a control and a treatment) during the calibration (pre-treatment) and post5 treatment periods. This study characterizes seasonal water table and flow response to rainfall during the calibration period and tests a change detection technique of moving sums of recursive residuals (MOSUM) to select calibration periods for each controltreatment watershed pair when the regression coefficients for daily water table elevation (WTE) were most stable to reduce regression model uncertainty. The control and treatment watersheds included 1-3 year intensively managed loblolly pine (Pinus taeda L.) with natural understory, same age loblolly pine intercropped with switchgrass (Panicum virgatum), 14-15 year thinned loblolly pine with natural understory (control), and switchgrass only. Although monitoring during the calibration period spanned 2009 to 2012, silvicultural operational practices that occurred during this period such as harvesting of existing stand and site preparation for pine and switchgrass establishment may have acted as external factors, potentially shifting hydrologic calibration relationships between control and treatment watersheds. Results indicated that MOSUM was able to detect significant changes in regression parameters for WTE due to silvicultural operations. This approach also minimized uncertainty of calibration relationships which could otherwise mask marginal treatment effects. All calibration relationships developed using this MOSUM method were quantifiable, strong, and consistent with Nash-Sutcliffe Efficiency (NSE) greater than 0.97 for WTE and NSE greater than 0.92 for daily flow, indicating its applicability for choosing calibration periods of paired watershed studies.
HESSD

12, 245-279, 2015

Hydrologic

calibration of paired watersheds using

a MOSUM approach

H. Ssegane et al.

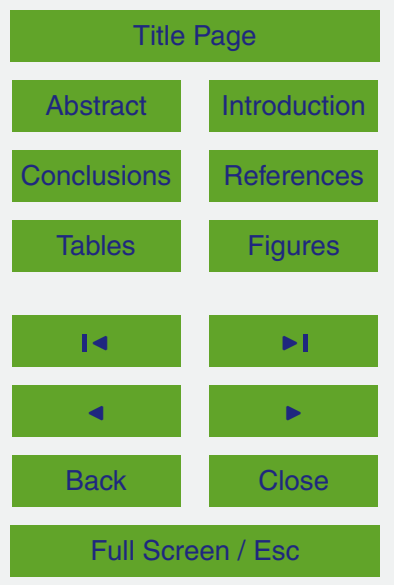

Printer-friendly Version

Interactive Discussion 


\section{Introduction}

Forty percent of the projected growth of global energy demand in 2035 will come from low carbon sources such as biofuels, geothermal, solar, wind, and nuclear (Birol, 2014). By 2035, the use of biofuels is projected to triple compared to the 2011 baseline of 51.3 million barrels of oil equivalent per day $\left(\mathrm{mboed}^{-1}\right)$ with advanced biofuels supplying $20 \%$ of this demand (Birol, 2014). However, achievement of such sustainable bioenergy industry requires accurate assessment of effects of biofuel-driven land use changes as constrained by competing land demands for food and fiber production and urban sprawl. Therefore, the need to effectively optimize current land use practices to meet future biofuels production demands with limited environmental impact requires studies to quantify effects of such transitions of land use change on local and regional hydrology and water quality (Georgescu and Lobell, 2010).

Vast areas of southeastern US Coastal plain and Gulf Coast regions are covered by pine forests (Pinus spp.) planted primarily for timber production. A potential option for biofuel feedstock production within planted pine systems is intercropping of a perennial biofuel crop, such as switchgrass (Panicum virgatum) between rows of planted pine. However, documentation of sustainability of this system, including impact on water resources, must be quantified and compared to current forest management practices. In a traditional setting, pine is planted in rows, often in raised bed, and the space between beds are occupied by natural vegetation. Replacing the natural understory with switchgrass introduces a relatively uniform vegetation structure between pine beds and, thus, reduces intensity of runoff (Blanco-Canqui et al., 2004; Schmer et al., 2011). Most recently, Albaugh et al. (2014) studied the effects of intercropping switchgrass in pine stands on water use and gross primary productivity using 3 year (2009-2011) data from plot-scale experiments in an upper coastal plain site of North Carolina, USA. They reported an increase in water uptake (transpiration) by switchgrass during the peak growing season, with the total annual evapotranspiration (ET)
HESSD

$12,245-279,2015$

Hydrologic

calibration of paired watersheds using

a MOSUM approach

H. Ssegane et al.

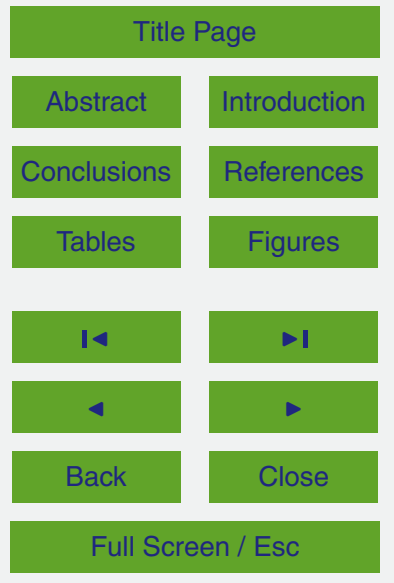

Printer-friendly Version

Interactive Discussion 
higher from the traditional pine stand than switchgrass. However, there have been no such studies completed on a watershed-scale basis.

A number of studies (McCarthy et al., 1991, 1992; Skaggs et al., 2011; Amatya et al., 1996, 1998a, 2000, 2003, 2006; Beltran et al., 2010) have been conducted on 5 pine plantations with improved drainage in low gradient coastal North Carolina to evaluate effects of both silvicultural and water management practices on downstream water quantity and quality. Most of these studies were based on a classical paired watershed approach, where two neighboring watersheds (one control and one treatment) were concurrently monitored during calibration (pre-treatment) and post-treatment periods 10 (Clausen and Spooner, 1993; Loftis et al., 2001; Andreassen, 2004). A statistically significant relationship between control and treatment watersheds is established during calibration such that any significant shift detected during treatment is attributable to treatment effects (Zegre et al., 2010). The paired watershed approach also offers the ability to identify roles of forest cover, internal watershed behavior, and climate variabil15 ity to establish a "baseline" for reference (Zegre, 2008).

The paired watershed approach has been extensively used to assess effectiveness of conservation practices (King et al., 2008; Tomer and Schilling, 2009; Jokela and Casler, 2011; Lemke et al., 2011), changes in water yield due to afforestation and harvesting or deforestation (Bosch and Hewlett, 1982; Fahley and Jackson, 1997; Brown et al., 2005; Amatya et al., 2006; Edwards and Troendle, 2008; Chescheir et al., 2009; Bren and Lane, 2014), and best management practices for controlling sediment transport, nitrogen and phosphorus runoff and leachate (Jaynes et al., 2004). This approach continues to be used on low-order watersheds as the primary method for impact assessments (Bren and Lane, 2014) although its validity for predicting effects on large flooding events has been challenged (Alila et al., 2009). In a recent study Bren and Lane (2014) analyzed high-quality data sequences from the pre-treatment phase of two Australian paired catchment projects to answer key questions on (a) the gain in information over time as the calibration period extends, in other words, an "optimal length" of calibration, (b) the relative gain or loss of information when using daily or monthly or
HESSD

12, 245-279, 2015

Hydrologic

calibration of paired watersheds using

a MOSUM approach

H. Ssegane et al.

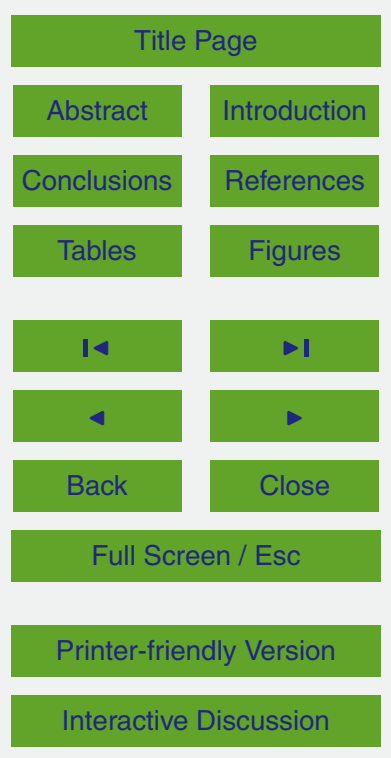


annual data, and the effect of autocorrelation of residuals in calibration models, and (c) how the calibration development should be monitored in real time, to obtain the most efficient calibration.

Structural changes of regression parameters in the calibration regression models of 5 paired watersheds due to pest infestations or anthropogenic activities other than the treatment may yield erroneous inferences of treatment effects (e.g., Vogl and Lopes, 2009). This issue is similar to question (c) addressed by Bren and Lane (2014) to obtain the most efficient calibration. Several studies have demonstrated significant changes in hydrology and nutrient concentrations and loads on forest sites due to silvicultural and 10 water management operations (Amatya et al., 1996, 1998a, 2000; Beltran et al., 2010; Arthur et al., 1998; Lebo and Herrmann, 1998). Bliss and Comerford (2002) identified a decrease in water table right after harvesting and later an increase in water for about four months following harvesting of flat woods in Florida. Arthur et al. (1998), using a paired watershed approach to quantify impacts associated with tree harvesting and 15 best management practices on water yield and water quality, reported increased water yield in the year following clear cutting of woody species in a Kentucky forest. Xu et al. (2002) attributed the rise of water table following vegetation removal to reduced transpiration because impacts of harvesting on forested watershed hydrology were more pronounced during the growing season. However, Laurén et al. (2009) demonstrated how uncertainty in pre-treatment data and thus the calibration relationship of paired watershed studies may influence estimates of the magnitude and duration of the treatment effects. Their monitoring of phosphorous loads on two independent paired catchments in Finland before and after clear-cutting showed that small treatment effects may be masked by uncertainty of the pre-treatment data.

In this study, a field experiment was set up in early 2009 to quantify watershed-scale effects of managing pine forests intercropped with switchgrass on poorly drained soils in Carteret County, NC on hydrology (i.e. water table elevation and flow) of the treatment watersheds using a paired watershed approach. Accordingly, this study required initial silvicultural operations to establish switchgrass growth during the period when
HESSD

12, 245-279, 2015

Hydrologic

calibration of paired watersheds using

a MOSUM approach

H. Ssegane et al.

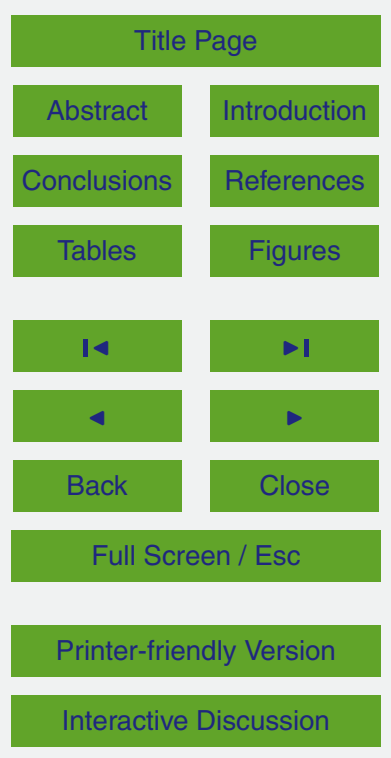


monitoring was going on for calibration. These silvicultural operations included harvesting, site preparation (bedding, shearing and raking) as well as herbaceous broadleaf control as described by Albaugh et al. (2012) in their plot-scale study. All or some of these activities may have potential to impact the surface soil hydraulic properties and, 5 thus, impact the water table elevation, drainage outflow, and nutrient and sediment dynamics (Albaugh et al., 2012). For example, Skaggs et al. (2006) found 20-30 times higher effective hydraulic conductivity for the top $90 \mathrm{~cm}$ of the Deloss fine sandy loam soil for matured plantation forest compared to the data published by NRCS Soil Survey prior to harvest at the Carteret County, NC study site. They observed that harvest 10 did not appear to affect those values but site preparation for regeneration, including bedding, reduced the effective hydraulic conductivity to values typically assumed for this series, Developing a calibration regression relationship with data collected from the control and treatment watersheds undergoing such disturbances violates the assumption of the paired watershed approach when both watersheds should be free of external disturbances other than the treatment to be implemented.

Therefore, the specific objective of this study was to develop regression models that minimize effects of external factors by minimizing uncertainty in the regression parameters based on their structural stability. Data monitoring for the pre-treatment calibration period were collected during 2009 to 2012 during which time silvicultural practices were conducted; these may have acted as external factors, affecting pre-treatment hydrologic relationships between control and treatment watersheds. A change detection technique of moving sums of recursive residuals (MOSUMS: Bauer and Hackl, 1978; Chu et al., 1995; Zeileis et al., 2013) is used to minimize the effects of these external factors on the uncertainty of parameters of the calibration models. Utilizing MOSUMS 2009-2012 data when the effect of external factors was minimal and the regression coefficients were most stable and also significant.

HESSD

12, 245-279, 2015

Hydrologic

calibration of paired watersheds using

a MOSUM approach

H. Ssegane et al.

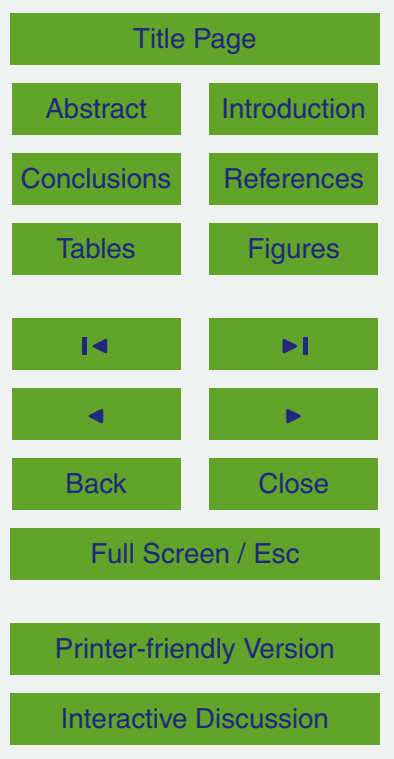




\section{Methods and materials}

\subsection{Site description}

The study site is on Carteret 7 tract, located in Carteret County, North Carolina (Latitude of 34.8220 and Longitude of -76.6680), was established by Weyerhaeuser Com-

5 pany and Catchlight Energy LLC, a joint venture between Chevron and Weyerhaeuser Company, on land owned and managed by Weyerhaeuser Company. The site consists of four small artificially drained experimental watersheds (Fig. 1: D0 $=27.5 \mathrm{ha}$, $\mathrm{D} 1=26.3 \mathrm{ha}, \mathrm{D} 2=25.9 \mathrm{ha}$, and D3 $=27.1 \mathrm{ha}$ ). The D1-D3 watersheds have long been established and used for previous studies while watershed D0 was established in 2009 for this study. These watersheds were surrounded by forested land in the north, south, and west, and by agricultural land in the east. The boundary roads hydrologically separated the watersheds from influences on neighboring lands, while raised beds $\approx 0.3 \mathrm{~m}$ ) minimize surface flow between watersheds (Amatya et al., 1996). McCarthy et al. (1991) characterized the topography of the site as flat Coastal Plain with a gradient of $0.1 \%$ and ground surface elevation at about $3 \mathrm{~m}$ a.s.l. The Deloss fine sandy loam soil on the site was classified as very poorly drained with a shallow water table under natural conditions. Drainage on each watershed was improved by using four parallel lateral ditches about 1.4-1.8 m deep, spaced $100 \mathrm{~m}$ apart (Fig. 1). Mean annual rainfall over a 21 year period was $1517 \mathrm{~mm}$ with a $10-20 \%$ annual variation due to hurricanes and tropical storms (Amatya and Skaggs, 2011). Further descriptions of the site soil properties, climatic data, and forest vegetation are given by Amatya and Skaggs (2011), Amatya et al. (1996), McCarthy et al. (1991), and Tian et al. (2012).

\subsection{Weather and hydrologic data}

The four experimental watersheds (Fig. 1) were instrumented to measure and record weir stage $(\mathrm{cm})$, water table depth $(\mathrm{cm})$, water quality, and rainfall $(\mathrm{mm})$. Total rainfall on each watershed is collected with automatic tipping bucket rain gauges calibrated
HESSD

Hydrologic

calibration of paired watersheds using a MOSUM approach

H. Ssegane et al.

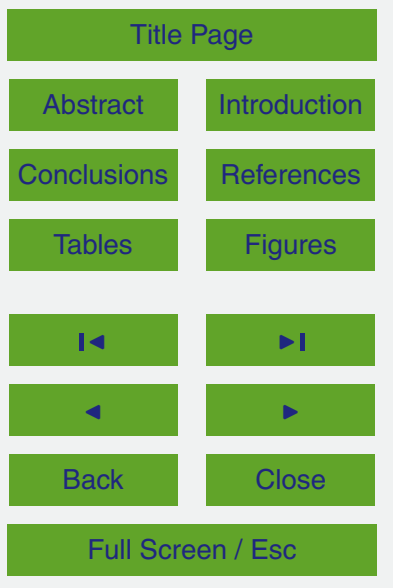

Printer-friendly Version

Interactive Discussion 
by manual gauge measurements in an open area. Air and soil temperatures $\left({ }^{\circ} \mathrm{C}\right)$, relative humidity $(\%)$, wind speed $\left(\mathrm{km} \mathrm{h}^{-1}\right)$, and solar radiation $\left(\mathrm{Wm}^{-2}\right)$ were measured and recorded on a 30 min interval using an onsite weather station. The wind speed anemometer and the relative humidity sensor were stationed at 3.4 and $2.3 \mathrm{~m}$ above 5 ground, respectively. The $30 \mathrm{~min}$ weather data was integrated to obtain daily average which was then used to calculate the Penman-Monteith-based potential evapotranspiration for a standard grass reference (REF-ET) for the site.

An adjustable height $120^{\circ} \mathrm{V}$-notch weir, located at the outlet of each watershed, measured drainage outflow by continuously recording water levels (stage) upstream and 10 downstream of the weir where the bottom of the V-notch was approximately $100 \mathrm{~cm}$ below average soil surface elevation for each watershed. Automatic stage recorders were installed to make stage measurements every $12 \mathrm{~min}$ upstream and downstream of a V-notch weir set about $0.3 \mathrm{~m}$ above the bottom of outlet ditch. A pump was installed in 1990 at the roadside collector ditch downstream of all watershed outlets 15 to minimize weir submergence during large events (Amatya et al., 1996). Flow rates $\left(\mathrm{m}^{3} \mathrm{~s}^{-1}\right)$ were computed using discharge-stage relationships for non-submerged and submerged weir conditions (Brater and King, 1996). 12 min flow rates were integrated to obtain daily totals normalized by watershed area $\left(\mathrm{mm}\right.$ day $\left.{ }^{-1}\right)$. Calculated daily flow values greater than the capacity of the downstream culvert during large storm events were capped to $45 \mathrm{~mm}$ day $^{-1}$, the approximate culvert drainage capacity (Amatya and Skaggs, 2011). Such data were excluded from analysis of treatment effects because of uncertainty due to highly submerged conditions. Computed flow data during weir submergence are susceptible to high uncertainty (USGS, 1997; Amatya et al., 1998b). Water table elevation (WTE) is continuously recorded on an hourly basis at the front and back experimental plots of each watershed (Fig. 1). The average of the back and front WTE was assumed as the representative WTE for each watershed.

\section{HESSD}

$12,245-279,2015$

Hydrologic

calibration of paired watersheds using

a MOSUM approach

H. Ssegane et al.

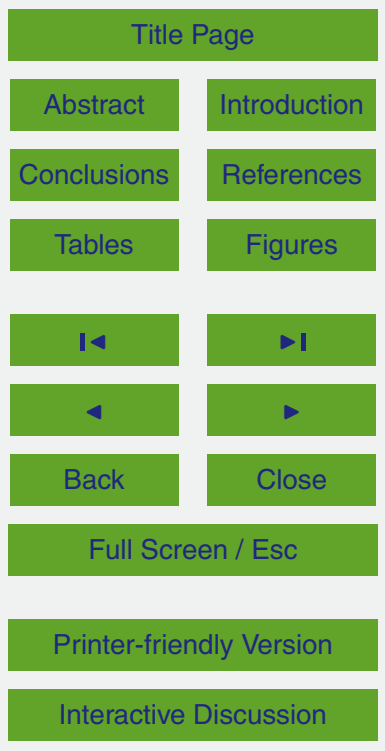




\subsection{Silvicultural operational and management practices}

The control watershed D2 (loblolly pine of 14-15 year old stands) was thinned (50\% reduction in basal area) in early 2009 (Fig. 2). Watersheds D0 and D1 were clear-cut by April 2009, while $85 \%$ of D3 was harvested by November 2009 and $100 \%$ by May

5 2010. Pine planting on D0 and D1 was completed by January 2010. Watershed D0 was left with a natural understory while on D1 the natural understory between the pine rows was cleared in December 2010 by shearing between the rows for switchgrass planting. Therefore, the watershed land cover conditions for D0 and D1 were similar up to December 2010. Initial broadcast of switchgrass seeds on D1 and D3 in August 2011 did not germinate due to excess wet conditions. However, the second phase of switchgrass seed broadcast between March and April 2012 yielded a much better germination resulting in a stand establishment between pine rows of D1, but coverage at D3 was still only about $15-20 \%$. Other management practices included broadleaf control on D1 and D3 in August 2011.

\subsection{Structural stability of calibration relationships}

To minimize effects of silvicultural operations as external factors on uncertainty of calibration regression models and provide a more reliable calibration with adequate length, as noted by Bren and Lane (2014), a change detection technique of moving sums (MOSUM) of recursive residuals (Bauer and Hackl, 1978; Chu et al., 1995) was used to select the longest calibration periods for each control-treatment watershed pair (D1-D2 and D3-D2). There were no management operations on D0 after pine planting. However, MOSUM test was carried out for the D0-D2 calibration model as a reference for testing false identification of structural breaks. The MOSUM is a variant of the cumulative sums (CUSUM) method (Brown et al., 1975). Both methods test the null hypothesis that the regression coefficients of a linear regression are constant over time against an alternative hypothesis that the coefficients change over time due to extraneous factors. The CUSUM and the MOSUM tests have been applied to detect temporal changes in
HESSD

12, 245-279, 2015

Hydrologic

calibration of paired watersheds using

a MOSUM approach

H. Ssegane et al.

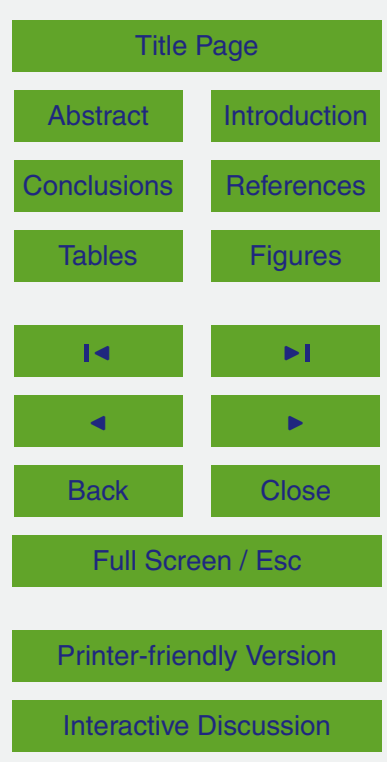


areas of landuse and land cover, hydrology, and national economic indicators (Ghosh, 2009; Vogl and Lopes, 2009; Verbesselt et al., 2010, 2012; Olmo et al., 2011; Tiwari et al., 2012; Webb et al., 2012; de Jong et al., 2013). This study used the MOSUM of recursive residuals (Eq. 1) because it is more sensitive to parameters that are tem5 porarily unstable than the CUSUM because cumulated sums become less sensitive as the number of residuals becomes larger (Chu et al., 1995).

$$
\begin{aligned}
& M_{r}=\sum_{i=r-w+1}^{r} \frac{W_{r}}{\sigma} ; \quad r=p+w, \ldots, N \\
& W_{r}=\frac{y_{r}-\boldsymbol{x}_{r}^{\prime} b_{r-1}}{\sqrt{\left(1+\boldsymbol{x}_{r}^{\prime}\left(\mathbf{X}_{r-1}^{\prime} \mathbf{x}_{r-1}\right)^{-1} \boldsymbol{x}_{r}\right)}}
\end{aligned}
$$

$\sigma^{2}=\frac{1}{N-p} \sum_{i=p+1}^{N}\left(W_{i}-\bar{W}\right)$ and $\bar{W}=\frac{1}{N-p} \sum_{i=p+1}^{N} W_{i}$,

10 where $M_{r}$ is the $r$ th moving sum of recursive residuals with a data window size of $w, p$ is the total number of regression coefficients, $N$ is the total number of data samples, $W_{r}$ is the $r$ th recursive residual, $y_{r}$ is the $r$ th observation of the response variable, $x_{r}{ }_{r}$ is the $r$ th row vector of the explanatory variables, $b_{r-1}$ is the ordinary least squares estimate of parameter $b$ using data before the $r$ th time step, $\sigma^{2}$ and $\bar{W}$ are the variance and mean estimates of the recursive residuals $W_{i}$. The $\mathbf{X}_{r-1}$ and $\mathbf{X}_{r-1}^{\prime}$ are the $[n-1 \times p]$ regressor matrix and its transpose using data before the $r$ th time step.

The MOSUM test for change detection was implemented in R-software environment using the strucchange package (Zeileis et al., 2013), which follows a three step procedure. The first step checks for existence of structural change based on the assumption that variability of the moving sums of recursive residuals under structural stability follows a Brownian motion (a random walk) with an expected mean of zero. Therefore,
HESSD

$12,245-279,2015$

Hydrologic

calibration of paired watersheds using

a MOSUM approach

H. Ssegane et al.

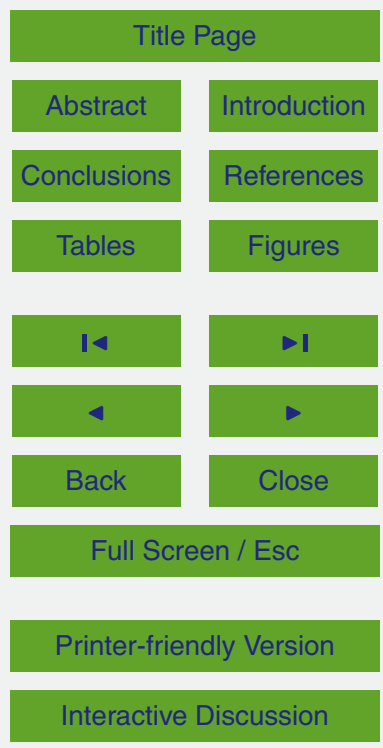


if the MOSUM crosses the $95 \%$ confidence boundary, then structural change is detected. For details on the technical basis and the asymptotic function of the $95 \%$ confidence boundary, refer to Zeileis et al. (2013). When structural change is detected in the first step, then steps two and three determine the number and location of change 5 points also known as break points or break dates. Break points and corresponding $95 \%$ confidence intervals are estimated based on methods developed by Bai (1994, 1997) and Bai and Perron (1998, 2003a, b) and implemented by Zeileis et al. (2013). The second step determines the number of break points by minimizing the Bayesian Information Criterion. However, one can predefine the maximum number of breakpoints 10 for a given time series. For this analysis, four breakpoints were arbitrarily assumed to correspond to potential effects of clear-cutting, shearing and bedding, pine planting, and planting of switchgrass. The third step iteratively determines the location of break points by minimizing the regression sum of squares.

Based on the above procedural implementation of MOSUM and the fact that analy15 ses are made on moving sums, the location where the MOSUM cross the $95 \%$ confidence boundary is not always the location of the breakpoints. Also, when the MOSUM return inside the boundary, it does not mean the relationship has regained the previous structural stability. Finally, strength of the linear relationship, size of the moving window, and number of predetermined breakpoints influence the location of the breakpoints. A data window size of 30 days was used to calculate moving sums of recursive residuals and a significance level of $5 \%(\alpha=0.05)$ was used to detect structural changes in regression coefficients. Only the water table elevation data was used to determine pairwise control-treatment calibration periods for both daily water table elevation and daily flow data because for these low-gradient artificially drained coastal plain soils, the depth of the water table is the main driver of the hydrology (Amatya et al., 1996; Skaggs et al., 2011).

\section{HESSD}

12, 245-279, 2015

Hydrologic

calibration of paired watersheds using

a MOSUM approach

H. Ssegane et al.

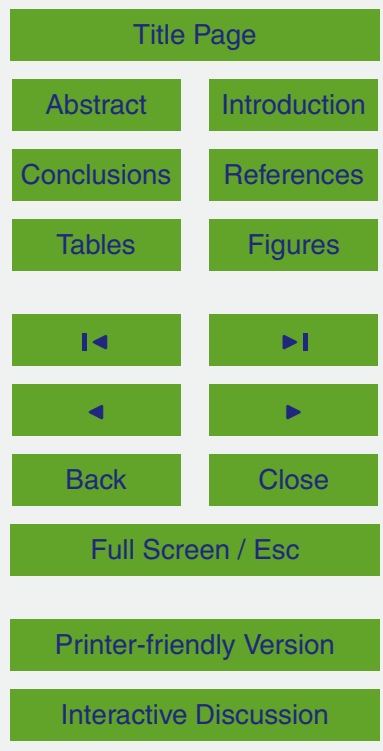




\subsection{Regression analysis}

Based on data spanning the stable calibration periods as estimated by the MOSUM test, a non-parametric bootstrap geometric mean regression (Plotnick, 1989; Efron and Tibshirani, 1994; Elkinton et al., 1996) was used to determine the calibration regression 5 coefficients and their respective $95 \%$ confidence intervals. This regression approach was used because it minimizes effects of temporal autocorrelation and consistent with a recent recommendation by Bren and Lane (2014) that any paired watershed approach should address non-normality and autocorrelation of residuals. Furthermore, bootstrapped standard errors and confidence intervals are smaller than ordinary least

10 squared errors. The geometric mean regression, also known as the reduced major axis regression is suited for paired watershed analysis because it assumes errors are associated with both dependent (treatment watershed) and the independent (control watershed) variables (Friedman et al., 2013). One thousand bootstrap samples were used to estimate regression coefficients and corresponding confidence intervals.

\section{Results}

\subsection{Water table elevation response to rainfall}

Rainfall during 2009 and 2012 were relatively similar and well distributed throughout each year with some large events in the fall. Rainfall distributions of 2010 and 2011 were also similar with most events in the fall and the winter. The driest year was 2011 with annual rainfall of $1181.7 \mathrm{~mm}$ and a net precipitation (difference between rainfall and REF-ET) deficit of $53 \mathrm{~mm}$ while 2010 was the wettest with annual rainfall of $1420.6 \mathrm{~mm}$ and a net precipitation surplus of $275.7 \mathrm{~mm}$. Analysis of rainfall measured at each watershed shows similar rainfall distributions across all watersheds each year with slight differences in actual rainfall amount. These annual differences were similar to the rainfall observed at the weather station. However, on average, there was
HESSD

12, 245-279, 2015

Hydrologic

calibration of paired watersheds using

a MOSUM approach

H. Ssegane et al.

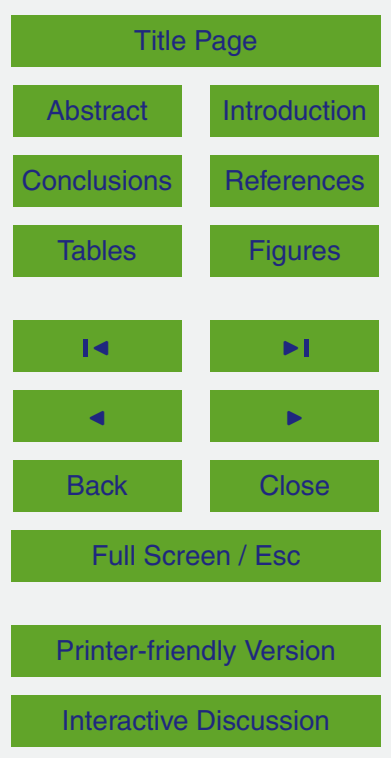


a general negative linear trend of average annual rainfall from D0 with the highest rainfall $(1348.6 \mathrm{~mm})$ and D3 with the lowest rainfall $(1234.2 \mathrm{~mm})$. A simialr trend was also observed for the same site by Amatya et al. (1996).

Seasonal climatic and vegetation dynamics affected WTE (Figs. 3-5), such that the 5 WTE dropped below $1.5 \mathrm{~m}$ (above sea level) in the summer with occasional large rainfall events that temporarily raised the water table to the soil surface with ponding. For example, a large area of the watershed D3 had ponded conditions as a result of large events with daily rainfall exceeding $150 \mathrm{~mm}$ in late September 2010 and $100 \mathrm{~mm}$ in mid-October 2011 on wet antecedent conditions. Vegetation effects were reflected by 10 higher WTE on all three treatment watersheds (young pine or emergent vegetation with a shallow root system and less evaporative demand) than the control watershed (D2: 14-15 year pine with deep root system and high evaporative demand) during the growing season. However, water table response to large storm events, characterized by a rise to the soil surface, was similar among all watersheds; an observation con15 sistent with previous studies at this site (Amatya and Skaggs, 2011; Skaggs et al., 2011). The average difference of WTE between D0 and D2 was $17.3 \pm 0.9 \mathrm{~cm}( \pm 95 \%$ $\mathrm{Cl}), 22.5 \pm 0.8 \mathrm{~cm}$ between D1 and D2, and $9.1 \pm 0.6 \mathrm{~cm}$ between D3 and D2. The above differences between control and treatment watersheds for the 2009 to 2012 pretreatment calibration period were significant and greater than the historical differences 20 (Ssegane et al., 2013), except between (D0 and D2) as D0 was established only in 2009.

The greater average WTE difference between D1 and D2 was due to clear-cutting of D1 in 2009 and shearing of the understory between pine-rows in December 2010 and switchgrass seed broadcast in August 2010, and April 2012 (Fig. 2). The average was later (between November 2009 to May 2010) than at D1 (Table 1). Another reason for this difference was the high variability between the WTE of the front and back plots for D3 (soil heterogeneity) compared to similar plots for D0, D1, and D2. A similar trend was evident in the maximum single day WTE difference between the control and

HESSD

12, 245-279, 2015

Hydrologic

calibration of paired watersheds using

a MOSUM approach

H. Ssegane et al.

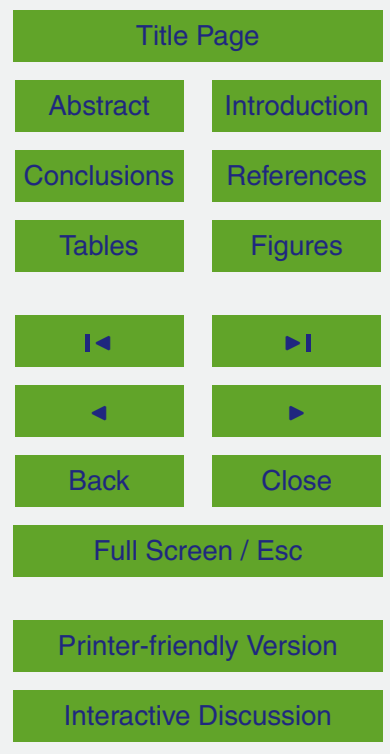

(i) 
treatment watersheds. The maximum difference between D1 and D2 was $86.3 \mathrm{~cm}$ on 28 June 2009 during shearing and bedding. The maximum difference between D3 and D2 $(41.0 \mathrm{~cm})$ was observed on 28 August 2011 after shearing and raking of D3 for switchgrass seed broadcasting (Fig. 2).

\section{3.2 Effects of harvesting on seasonal WTE and flow}

Prior to $100 \%$ harvesting of D1, the D1 WTE was higher than D2 (Table 1; January to April 2009), consistent with earlier studies (Ssegane et al., 2013; Amatya and Skaggs, 2011; Amatya et al., 2006) while D2 flow was greater than D1 flow (Tables 1-2). However, after harvesting of D1 (2010 to 2012), the difference in D1 and D2 flow was mostly positive (D1 flow greater than D2 flow) during the growing season and negative (D2 flow greater than D1 flow) during the dormant season. The negative differences in flow during the dormant season, dominated by high water tables and low ET that minimally affects flow, are attributable to intrinsic differences in watershed soils (Blanton et al., 1998) and micro-topography including possible lateral seepage from $D 1$ to a roadside drainage ditch at the north boarder of D1depicted by pre-harvest behavior (D2 flow greater than D1 flow). The large positive differences between D1 and D2 during the growing season (specifically from August to October) may be attributed to diminishing ET rates of the emergent vegetation at D1 (Sampson et al., 2011) yet transpiration rates of D2 (relatively old pine with less areal coverage of understory) were still high 20 and thus higher flows on D1. The exceptions to the above trend included September and October 2010, and August and September 2012. A possible explanation to these exceptions was derived from Fig. 4. The water table on D1 was consistently shallower, compared to D2. During the dormant season, the difference in water table became less due to the above stated reasons such that the tendency of D1 to produce less

flow than D2 dominated. During the growing season, the water table was considerably deeper in D2 and the flow from D2 was less compared to D1. Very large rainfall events in September 2010 and October 2011 compensated for the difference in the WTE and the WTE reached almost to the soil surface for both D1 and D2. Under these condi-
HESSD

$12,245-279,2015$

Hydrologic

calibration of paired watersheds using

a MOSUM approach

H. Ssegane et al.

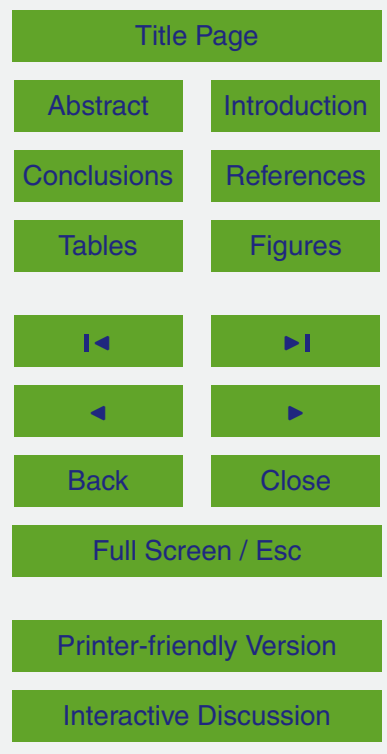


tions, the role of vegetation became less dominant compared to the tendency of one watershed to produce less flow than the other in response to these events.

Similar seasonal shifts observed on D1 and D2 were also observed on WTE and flow differences between D3 and D2 (Table 2). This seasonal shift in hydrologic behav-

5 ior was further moderated by seasonal variation of climatic variables, site preparation for switchgrass seed broadcasting on D1 and D3, and weir submergence and backflow mostly on D3. For example, the weir outlets at all four watersheds were submerged (downstream stage greater than the v-notch of the weir) on 27 September to 4 October 2010 and 26 January 2011 with backflow on D3 (26 January 2011) due to failure of 10 the downstream pump which was installed to minimize such incidences. The total incidences of submergence and backflow on all watersheds occurred on 0.80 and $0.04 \%$ of the time, respectively, based on 12 min stage data during this time. The D3 flow did not momentarily increase compared to D2 after $85 \%$ of harvesting on D3 in November 2009 because it was during the dormant season with minimal ET demands at the end of the harvesting, such that any observed differences in D2 and D3 flows were similar to pre-harvest conditions (D2 flow greater than D3 flow). Note that prior to its harvest D3 was a 35 year old stand compared to D2 which was a 12 year old stand thinned in early 2009. Effects of vigorous emerging vegetation with increased leaf area index (LAI), particularly in 2010, a year after harvest of D1 and D3 may have also resulted in some negative differences in some months of the growing season. Sampson et al. (2011) noted that in coastal loblolly pine stands, herbaceous and arborescent species can dominate the site LAI for many years after a harvest (followed by planting). The observed seasonal shifts require minimum uncertainty in the regression parameters of calibration equations such that any small changes in hydrologic conditions are not masked by large standard errors.

\subsection{MOSUM change detection in pairwise calibration periods}

Movement of MOSUM outside the $95 \%$ confidence bounds (Fig. 6; horizontal dotted lines) is indicative of structural break in stability of regression coefficients. However,

HESSD

12, 245-279, 2015

Hydrologic

calibration of paired watersheds using

a MOSUM approach

H. Ssegane et al.

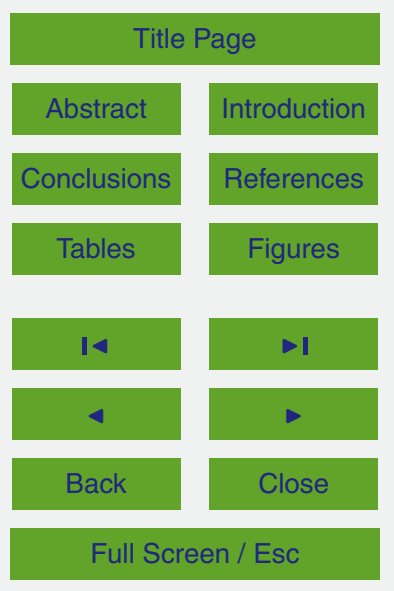

Printer-friendly Version

Interactive Discussion 
return of the MOSUM within the confidence bounds does not imply return to previous state of stability. The points when the MOSUM crosses the confidence bounds may not be the actual point when structural changes occurred because of the moving sums. Such points are represented by the vertical dotted lines known as break 5 points or break dates (with corresponding $95 \%$ confidence interval). There were no operational management practices on D0 after pine planting (Fig. 2) and the MOSUM (Fig. 6a) shows no structural break because it does not cross the $95 \%$ confidence interval. Therefore, the calibration period for D0 and D2 WTE and flow relationships included the period after pine planting on D0 to prior to the second phase of switchgrass 10 planting on D1 and D3. For the relationship between WTE of D1 and D2 (Fig. 6b), the first break point (between 26 and 28 March 2009) coincides with harvesting of D1 (Fig. 2 and Fig. 6), the second break point (between 1 and 10 October 2009) is one month after shearing and bedding on D1, the third break point (between 17 February and 4 March 2010) is one month after pine planting on D1, and the fourth break point 15 (between 24 and 30 August 2012) is about 3 months after the second re-broadcast of switchgrass seed on D1. Therefore, the actual calibration period with a minimal operational disturbance for D1 and D2 WTE and flow relationships is assumed as one month after pine planting on D1 (1 March 2010) to before preparations for the second phase of switchgrass seed broadcasting (31 March 2012) with 762 days altogether. Recently, Bren and Lane (2014) concluded that more complex models other than simple linear regression, achieved good calibration after 200 days of data. So this calibration period defined by the MOSUM method should be adequate.

The first break point for D3 and D2 WTE linear relationship (between 28 and 30 April 2009) was two months after $50 \%$ thinning of D2 (Figs. 2 and 6c) and coincided with the start of the growing season after thinning. The second break point (between 6 and 8 September 2009) was one month before $85 \%$ harvesting of D3. The authors believe this break point was most likely a false positive because no known operational activity occurred prior to this period. The third break point (between 9 and 14 November 2009) coincided with the $85 \%$ harvesting of D3, and the fourth break
HESSD

$12,245-279,2015$

Hydrologic

calibration of paired watersheds using

a MOSUM approach

H. Ssegane et al.

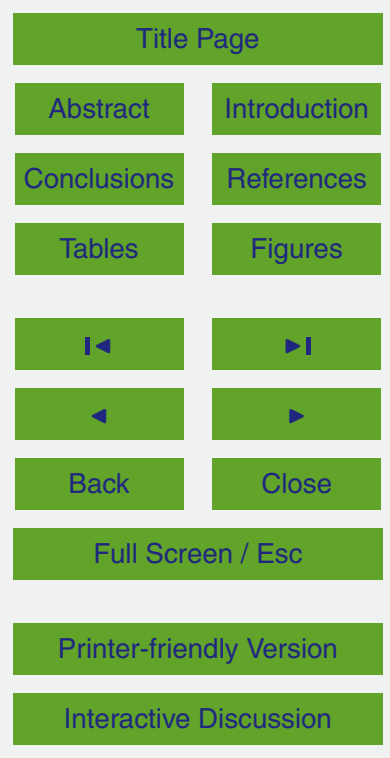


point (between 26 October and 10 November 2011) is about 2 months after the first seeding of switchgrass on D3 (15 August 2011). Harvesting of the final $15 \%$ of trees on D3 in May 2010 did not significantly alter the D3 and D2 WTE relationship due to emergent vegetation on previously harvested $85 \%$ portion of the watershed. Therefore, the 5 calibration period for D3 and D2 WTE and flow relationships was between the end of $85 \%$ harvesting of D3 (1 December 2009) and prior to preparations for the first phase of switchgrass planting (31 July 2011), with 608 days altogether. Again this is much longer than a threshold of 200 days recently suggested by Bren and Lane (2014).

\subsection{Pairwise calibration with stable regression relationships}

10 The coefficient of determination $\left(R^{2}\right)$, Nash-Sutcliffe efficiency (NSE), and the root mean squared error (RMSE) were indicative of strong, quantifiable, and predictable relationships between hydrologic responses of control and treatment watersheds (Fig. 7). For $R^{2}\left(0 \leq R^{2} \leq 1.0\right)$, and NSE $(-\infty \leq \mathrm{NSE} \leq 1.0)$, a value of 1.0 is indicative of an optimal model. Therefore, the calibration equations show that the two hydrologic responses of the control watershed (WTE and flow) are strong predictors of similar responses at treatment watersheds and, thus can serve as significant predictors of treatment effects using a paired watershed approach.

Use of all 2009 to 2012 data (the period after harvesting to prior to switchgrass planting) gave significantly different calibration equations with relatively weaker but not 20 significantly different regression statistics (lower $R^{2}$, and NSE, and higher RMSE). For the WTE relationships between D1 and D2, and between D3 and D2 using all data, the slopes are not significantly different from the slopes of the MOSUM data but the intercepts were significantly different. The daily flow relationships using all data, however, gave significantly different intercepts and slopes compared to MOSUM data based cal-
HESSD

$12,245-279,2015$

Hydrologic

calibration of paired watersheds using

a MOSUM approach

H. Ssegane et al.

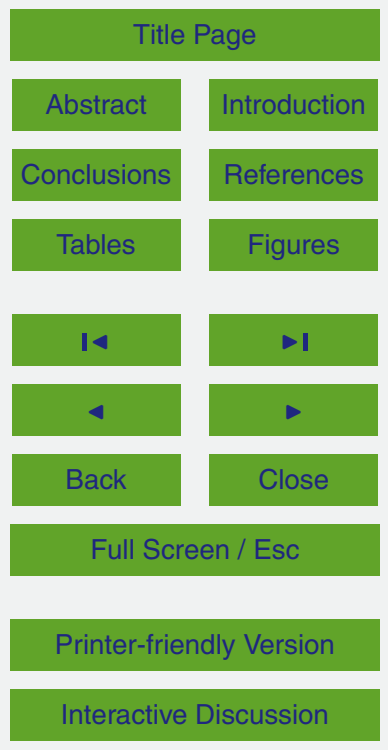


to MOSUM based data will potentially result in significantly different treatment effects, specifically as it pertains to the quantity and duration of treatment effect.

\section{Discussion}

\subsection{Uncertainty of calibration relationships}

5 The paired calibration relationships (Fig. 7) were developed using bootstrap geometric mean regression and data measured during periods with non-significant shifts in the regression coefficients due to operational practices. Compared to the ordinary leastsquares (OLS) regression, the geometric mean regression minimizes effects of data uncertainty on regression coefficients by simultaneously minimizing both the explana10 tory ( $x$-errors) and response ( $y$-errors) errors (Plotnick, 1989). However, both methods are not structured to detect significant temporal shifts in regression coefficients and, thus, the use of MOSUM test. Figure 8 is a sample comparison of the uncertainty of regression coefficients presented as a frequency distribution obtained by using 1000 bootstrap samples when MOSUM data (period with stable regression coefficients)

15 was used and when all calibration data (after harvesting to start of the treatment period) was used. The top two graphs are frequency distribution of intercept and slope with their respective means as solid vertical lines on MOSUM data (1 March 2010 to 31 March 2012), while the bottom graphs correspond to coefficients when all data (1 May 2009 to 31 March 2012) was used.

The slope of the MOSUM data, 0.947 [ $95 \% \mathrm{Cl}$ of $0.935-0.959$ ] is not significantly different from the slope of all data, 0.951 [95\% $\mathrm{Cl}$ of $0.93-0.971$ ] based on their respective $95 \% \mathrm{Cl}$ (Fig. 8). However, the intercepts are significantly different (Fig. 8: compare $0.244[0.228,0.260]$ and $0.307[0.280,0.334])$ and thus the two calibration equations are significantly different. Although, the slopes of the two different periods are not significantly different, the uncertainty of the slope of all data is greater than the uncertainty of MOSUM data (Fig. 8) because the uncertainty bands of the lower plot (all data) are
HESSD

12, 245-279, 2015

Hydrologic

calibration of paired watersheds using

a MOSUM approach

H. Ssegane et al.

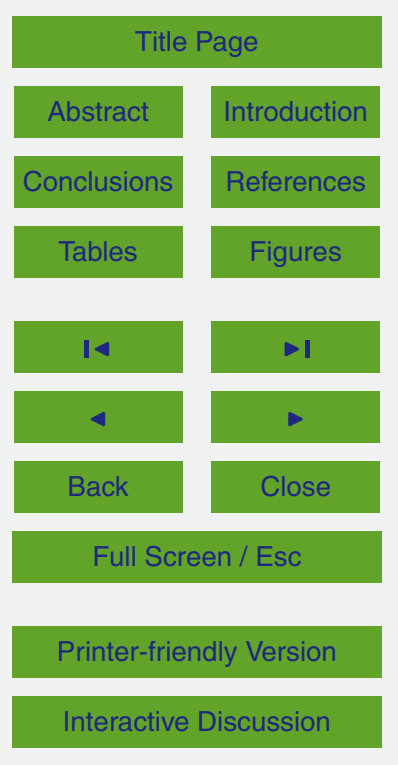


wider than the upper plot (MOSUM data), indicating the reduced uncertainty in regression parameters for the stable period. The model uncertainty is also reflected in the model fit performance statistics of NSE (0.97 vs. 0.87$)$ and RMSE (0.084 vs. $0.162 \mathrm{~m})$. Similar uncertainty trends were observed in daily WTE and flow calibration equations 5 between D3 and D2. For example, calibration relationships with a similar slope, but different intercepts, will consistently over-predict or under-predict the expected values during the post-treatment period.

\section{Conclusions}

Seasonal water table and flow response to rainfall were influenced by both the silvicultural management operations and vegetation on four treatment watersheds in the coastal plain of North Carolina. This study laid out protocols to develop significant, efficient, stable, and predictable calibration relationships required to quantify hydrologic effects of intercropping switchgrass and pine, and conversion of pine forest to entirely switchgrass on a watershed scale. Although the calibration data starts from 2009 (after clear-cutting of three pine forest stands, D0, D1 and D3) to 2012 (after broadcast of switchgrass seeds for its establishment in April to May 2012), a moving sums of recursive residuals (MOSUM) test was used to detect and omit the periods with instability in regression coefficients potentially due to external factors like silvicultural operations to establish switchgrass. The analysis procedure using MOSUM demonstrated three important findings. (1) Use of all 2009 to 2012 data gave significantly different calibration relationships between the control and treatment watersheds compared to use of only the data spanning the period when the linear regression coefficients of the WTE were stable (2) Use of the MOSUM test to determine calibration relationships with a data period potentially uninfluenced by external factors minimized uncertainty of calibration relationships. Length of the calibration periods determined by our analysis was also consistent with a recent finding by Bren and Lane (2014). (3) All calibration relationships were quantifiable, strong, and consistent $\left(R^{2}\right.$ and NSE greater than
HESSD

12, 245-279, 2015

Hydrologic

calibration of paired watersheds using

a MOSUM approach

H. Ssegane et al.

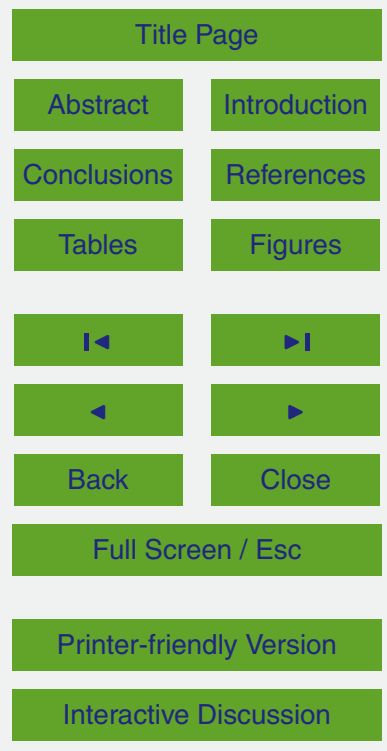


0.97 for WTE and $R^{2}$ and NSE greater than 0.92 for flow), a requirement for use of paired watershed approach. Therefore, the developed calibration relationships using a bootstrap geometric mean regression are adequate (with minimum uncertainty) to test significance of hydrologic effects of intercropping pines with switchgrass or $100 \%$ con-

5 version of a pine stand to switchgrass on the daily WTE and flow hydrologic responses at a watershed scale. This study will also have broader implications on similar ecohydrologic studies where significant calibration relationships that exclude periods with effects of non-treatment factors are warranted to quantify actual treatment effects using the paired watershed approach. The change detection approach using the MOSUM method should be particularly helpful to develop optimum and significant calibration relationship in studies where a long-term monitoring for the calibration period may be cost and time prohibitive.

Acknowledgements. The authors thank M. Cristina Negri of Argonne National Lab for the physical, technical, and financial support during preparation of this manuscript. The authors also would like to acknowledge Darren Miller of Weyerhaeuser Company for helpful review comments during manuscript preparation and Cliff Tyson of Weyerhaeuser Company for assisting with field data collection.

\section{References}

Albaugh, J. M., Sucre, E. B., Leggett, Z. H., Domec, J.-C., and King, J. S.: Evaluation of intercropped switchgrass establishment under a range of experimental site preparation treatments in a forested setting on the Lower Coastal Plain of North Carolina, USA, Biomass Bioenerg., 46, 673-682, 2012.

Albaugh, J. M., Domec, J.-C., Maire, C. A., Sucre, E. B., Leggett, Z. H., and King, J. S.: Gas exchange and stand-level estimates of water use and gross primary productivity in an experimental pine and switchgrass intercrop forestry system on the Lower Coastal Plain of North Carolina, USA, Agr. Forest Meteorol., 192-193, 27-40, 2014.
HESSD

12, 245-279, 2015

Hydrologic

calibration of paired watersheds using

a MOSUM approach

H. Ssegane et al.

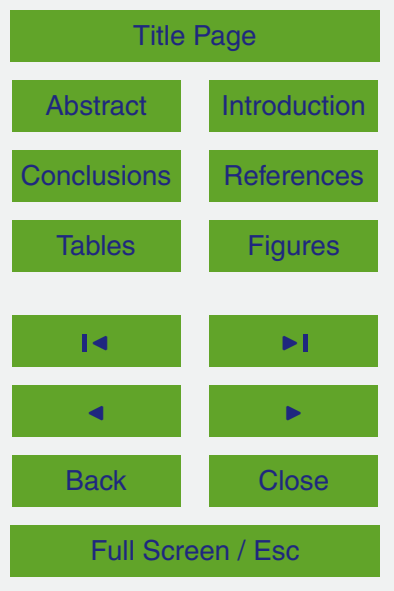

Printer-friendly Version

Interactive Discussion 
Alila, Y., Kuras, P. K., Schnorbus, M., and Hudson, R.: Forests and floods: a new paradigm sheds light on age-old controversies, Water Resour. Res., 45, W08416, doi:10.1029/2008WR007207, 2009.

Amatya, D. and Skaggs, R.: Long-term hydrology and water quality of a drained pine plantation in North Carolina, T. ASABE, 54, 2087-2098, 2011.

Amatya, D. M., Skaggs, R., and Gregory, J.: Effects of controlled drainage on the hydrology of drained pine plantations in the North Carolina coastal plain, J. Hydrol., 181, 211-232, 1996.

Amatya, D. M., Gilliam, J., Skaggs, R., Lebo, M., and Campbell, R.: Effects of controlled drainage on forest water quality, J. Environ. Qual., 27, 923-935, 1998a.

10 Amatya, D. M., Chescheir, G. M., and Skaggs, R. W.: Evaluation of Methods used in Estimating Outflow Rates in the Lower Coastal Watersheds, in: Proc. of the 1998 ASCE Intl Water Resources Engrg. Conference, edited by: Abt, S. R., Memphis, TN, 850-856, 1998b.

Amatya, D. M., Gregory, J. D., and Skaggs, R.: Effects of controlled drainage on storm event hydrology in Loblolly Pine plantation, JAWRA J. Am. Water Resour. As., 36, 175-190, 2000.

Amatya, D. M., Skaggs, R. W., Gilliam, J., and Hughes, J.: Effects of orifice-weir outlet on hydrology and water quality of a drained forested watershed, South. J. Appl. For., 27, 130142, 2003.

Amatya, D. M., Skaggs, R., Blanton, C., and Gilliam, J.: Hydrologic and Water Quality Effects of Harvesting and Regeneration of a Drained Pine Forest, in: Proc. of the ASABEWeyerhaeuser sponsored Intl Conference on Hydrology and Management of Forested Wetlands, edited by: Williams, T. M. and Nettles, J. E., New Bern, NC, April 8-12, 2006.

Andreassian, V.: Water and forests: from historical controversy to scientific debate, J. Hydrol., 291, 1-27, 2004.

Arthur, M., Coltharp, G., and Brown, D.: Effects of best management practices on forest streamwater quality in eastern Kentucky, Water Resour. Bull., 34, 481-495, 1998.

Bai, J.: Least squares estimation of a shift in linear processes, J. Time Ser. Anal., 15, 453-472, 1994.

Bai, J.: Estimating multiple breaks one at a time, Economet. Theor., 13, 315-352, 1997.

Bai, J. and Perron, P.: Estimating and testing linear models with multiple structural changes, Econometrica, 66, 47-78, 1998.

Bai, J. and Perron, P.: Computation and analysis of multiple structural change models, J. Appl. Econom., 18, 1-22, 2003a.

\section{HESSD}

$12,245-279,2015$

Hydrologic

calibration of paired watersheds using

a MOSUM approach

H. Ssegane et al.

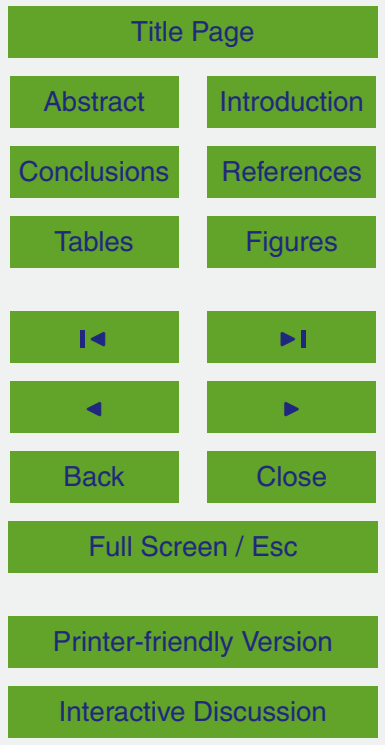


Bai, J. and Perron, P.: Critical values for multiple structural change tests, Econom. J., 6, 72-78, 2003b.

Bauer, P. and Hackl, P.: The use of MOSUMS for quality control, Technometrics, 20, 431-436, 1978.

5 Beltran, B. J., Amatya, D. M., Youssef, M., Jones, M., Callahan, T. J., Skaggs, R. W., and Nettles, J. E.: Impacts of Fertilization Additions on Water Quality of a Drained Pine Plantation in North Carolina: A Worst Case Scenario, J. Environ. Qual., 39, 293-303, 2010.

Birol, F.: World Energy Outlook 2013, International Energy Agency, Paris, France, 2014.

Blanco-Canqui, H., Gantzer, C., Anderson, S., Alberts, E., and Thompson, A.: Grass barrier and vegetative filter strip effectiveness in reducing runoff, sediment, nitrogen, and phosphorus loss, Soil Sci. Soc. Am. J., 68, 1670-1678, 2004.

Blanton, C. D., Skaggs, R. W., Amatya, D. M., and Chescheir, G. M.: Soil hydraulic property variations during harvest and regenaration of drained coastal pine plantations, Paper no. 982147, Amer. Soc. of Agr. Eng., St. Joseph, MI, 1998.

Bliss, C. and Comerford, N.: Forest harvesting influence on water table dynamics in a Florida flatwoods landscape, Soil Sci. Soc. Am. J., 66, 1344-1349, 2002.

Bosch, J. M. and Hewlett, J. D.: A review of catchment experiments to determine the effect of vegetation changes on water yield and ET, J. Hydrol., 55, 3-23, 1982.

Brater, E. F. and King, H. W.: Handbook of Hydraulics for the Solution of Hydraulic Engineering Problems, McGraw-Hill, New York, 6, 26590, 1996.

Bren, L. and Lane, P. N. J.: Optimal development of calibration equations for paired catchment projects, J. Hydrol., 519, 720-731, 2014.

Brown, R. L., Durbin, J., and Evans, J. M.: Techniques for testing the constancy of regression relationships over time, J. R. Stat. Soc. B Met., 37, 149-192, 1975.

Brown, T. C., Hobbins, M. T., and Ramirez, J. A.: Spatial distribution of water supply in the coterminous United States, J. Am. Water Resour. Ass., 44, 1474-1487, 2008.

Chescheir, G. M., Skaggs, R. W., and Amatya, D. M.: Quantifying the hydrologic impacts of afforestation in Uruguay: a paired watershed study, in: Proc., XIII World Forestry Congress, Buenos Aires, Argentina, 18-23 October, 2009.

so Chu, C.-S. J., Hornik, K., and Kaun, C.-M.: MOSUM tests for parameter constancy, Biometrika, 82, 603-617, 1995.

Clausen, J. and Spooner, J.: Paired Watershed Study Design, Office of Wetlands, Oceans and Watersheds, Environmental Protection Agency, Washington, DC (United States), 1993. 
de Jong, R., Verbesselt, J., Zeileis, A., and Schaepman, M. E.: Shifts in global vegetation activity trends, Remote Sensing, 5, 1117-1133, doi:10.3390/rs5031117, 2013.

Edwards, P. and Troendle, C. A.: Water yield and hydrology, in: Cumulative Watershed Effects of Fuels Management, edited by: Audin, L. J., US Forest Service, Northeastern Area, Newton

5 Square, Pa., available at: http://www.na.fs.fed.us/fire/cwe.shtm (last access: 15 June 2009), 2008.

Efron, B. and Tibshirani, R. J.: An Introduction to the Bootstrap, CRC Press, Boca Raton, FL, 1994.

Elkinton, J. S., Healy, W. M., Buonaccorsi, J. P., Boettner, G. H., Hazzard, A. M., and Smith, H. R.: Interactions among gypsy moths, white-footed mice, and acorns, Ecology, 77, 2332-2342, 1996.

Fahey, B. and Jackson, R.: Hydrological impacts of converting native forests and grasslands to pine plantations, South Island, New Zealand, Agr. Forest Meteorol., 84, 69-82, 1997.

Friedman, J., Bohonak, A. J., and Levine, R. A.: When are two pieces better than one: fitting and testing OLS and RMA regressions, Environmetrics, 24, 306-316, 2013.

Georgescu, M. and Lobell, D.: Perennial questions of hydrology and climate, Science, 330, 33-33, 2010.

Ghosh, S.: Import demand of crude oil and economic growth: evidence from India, Energ. Policy, 37, 699-702, 2009.

20 Jaynes, D., Dinnes, D., Meek, D., Karlen, D., Cambardella, C., and Colvin, T.: Using the late spring nitrate test to reduce nitrate loss within a watershed, J. Environ. Qual., 33, 669-677, 2004.

Jokela, W. and Casler, M.: Transport of phosphorus and nitrogen in surface runoff in a corn silage system: Paired watershed methodology and calibration period results, Canadian J. Soil Sci., 91, 479, 2011.

King, K., Smiley, P., Baker, B., and Fausey, N.: Validation of paired watersheds for assessing conservation practices in the Upper Big Walnut Creek watershed, Ohio, J. Soil Water Conserv., 63, 380-395, 2008.

Laurén, A., Heinonen, J., Koivusalo, H., Sarkkola, S., Tattari, S., Mattsson, T., Ahtiainen, M., Joensuu, S., Kokkonen, T., and Finér, L.: Implications of uncertainty in a pre-treatment dataset when estimating treatment effects in paired catchment studies: phosphorus loads from forest clear-cuts, Water Air Soil Poll., 196, 251-261, 2009.

Hydrologic

calibration of paired watersheds using

a MOSUM approach

H. Ssegane et al.

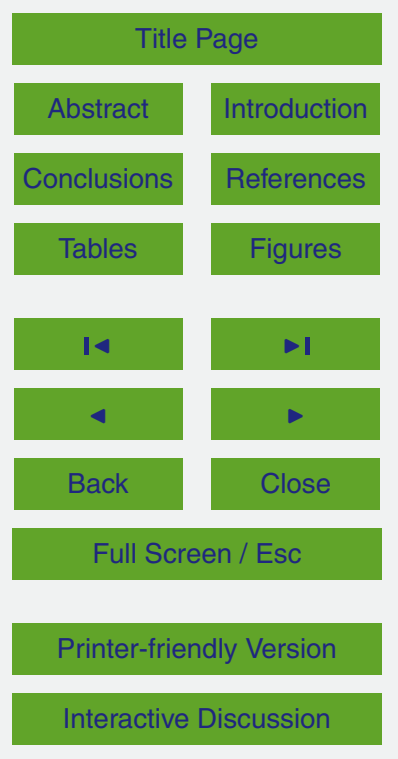


Lebo, M. E. and Herrmann, R. B.: Harvest impacts on forest outflow in coastal North Carolina, J. Environ. Quality, 27, 1382-1395, 1998.

Lemke, A., Kirkham, K., Lindenbaum, T., Herbert, M., Tear, T., Perry, W., and Herkert, J.: Evaluating agricultural best management practices in tile-drained subwatersheds of the Mackinaw

$5 \quad$ River, Illinois, J. Environ. Qual., 40, 1215-1228, 2011.

Loftis, J. C., MacDonald, L. H., Streett, S., Iyer, H. K., and Bunte, K.: Detecting cumulative watershed effects: the statistical power of pairing, J. Hydrol., 251, 49-64, 2001.

McCarthy, E., Skaggs, R., and Farnum, P.: Experimental determination of the hydrologic components of a drained forest watershed, T. ASAE, 34, 1991.

10 McCarthy, E., Flewelling, J., and Skaggs, R.: Hydrologic model for drained forest watershed, J. Irrig. Drain. E.-ASCE, 118, 242-255, 1992.

Olmo, J., Pilbeam, K., and Pouliot, W.: Detecting the presence of insider trading via structural break tests, J. Bank. Financ., 35, 2820-2828, 2011.

Plotnick, R. E.: Application of bootstrap methods to reduced major axis line fitting, Syst. Biol., 15 38, 144-153, 1989.

Sampson, D. A., Amatya, D. M., Blanton, C. D., and Skaggs, R. W.: Leaf area index (LAl) of Loblolly pine and Emergent Vegetation Following a Harvest, T. ASABE, 54, 2057-2066, 2011.

Schmer, M. R., Liebig, M., Vogel, K., and Mitchell, R. B.: Field-scale soil property changes under switchgrass managed for bioenergy, GCB Bioenergy, 3, 439-448, 2011.

Skaggs, R., Breve, M., and Gilliam, J.: Hydrologic and water quality impacts of agricultural drainage, Crit. Rev. Env. Sci. Tech., 24, 1-32, 1994.

Skaggs, R. W., Amatya, D. M., Chescheir, G. M., and Blanton, C. D.: Soil property changes during Loblolly Pine production, Paper Number: 068026, Am. Soc. Agr. Biol. Eng., St. Joseph, 25 Michigan, 2-12, 2006.

Skaggs, R. W., Chescheir, G. M., Fernandez, G. P., Amatya, D. M., and Diggs, J.: Effects of Land Use on Soil Properties and Hydrology of Drained Coastal Plain Watersheds, Trans. ASABE, 54, 1357-1365, 2011.

Ssegane, H., Amatya, D. M., Chescheir, G. M., Skaggs, W. R., Tollner, E. W., and Nettles, J. E.: 30 Consistency of hydrologic relationships of a paired watershed approach, Am. J. Climate Change, 2, 147-164, 2013.

Hydrologic

calibration of paired watersheds using

a MOSUM approach

H. Ssegane et al.

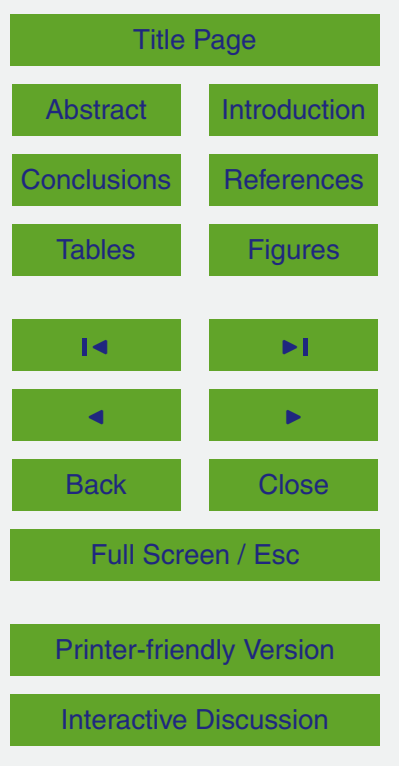


Tian, S., Youssef, M. A., Skaggs, R. W., Amatya, D. M., and Chescheir, G.: DRAINMODFOREST: integrated modeling of hydrology, soil carbon and nitrogen dynamics, and plant growth for drained forests, J. Environ. Qual., 41, 764-782, 2012.

Tiwari, A. K., Shahbaz, M., and Islam, F.: Does financial development increase rural-urban income inequality? Cointegration analysis in the case of Indian economy, Int. J. Soc. Econ., 40, 4-4, 2012.

Tomer, M. D. and Schilling, K. E.: A simple approach to distinguish land-use and climate-change effects on watershed hydrology, J. Hydrol., 376, 24-33, 2009.

USGS: National handbook of Recommended Methods for Water Data Acquisition, Office of 10 Water Data Coordination, Geological survey, US Department of the Interior, Reston, VA, 1997.

Verbesselt, J., Hyndman, R., Newnham, G., and Culvenor, D.: Detecting trend and seasonal changes in satellite image time series, Remote Sens. Environ., 114, 106-115, 2010.

Verbesselt, J., Zeileis, A., and Herold, M.: Near real-time disturbance detection using satellite 15 image time series, Remote Sens. Environ., 123, 98-108, 2012.

Vogl, A. L. and Lopes, V. L.: Evaluating watershed experiments through recursive residual analysis, J. Irrig. Drain. E.-ASCE, 136, 348-353, 2009.

Webb, A. A., Kathuria, A., and Turner, L.: Longer-term changes in streamflow following logging and mixed species eucalypt forest regeneration: the Karuah experiment, J. Hydrol., 464, 412-422, 2012.

Xu, Y.-J., Burger, J. A., Michael Aust, W., Patterson, S. C., Miwa, M., and Preston, D. P.: Changes in surface water table depth and soil physical properties after harvest and establishment of loblolly pine (Pinus taeda L.) in Atlantic coastal plain wetlands of South Carolina, Soil Till. Res., 63, 109-121, 2002.

Zegre, N.: The history and advancement of change detection methods in forest hydrology, 2008, in: Society of American Foresters Water Resources Working Group Newsletter, Society of American Foresters, Bethesda, MD, 1 pp., 2008.

Zégre, N., Skaugset, A. E., Som, N. A., McDonnell, J. J., Ganio, L. M.: In lieu of the paired catchment approach: hydrologic model change detection at the catchment scale, Water Resour. Res., 46, W11544, doi:10.1029/2009WR008601, 2010.

Zeileis, A., Leisch, F., Hornik, K., Kleiber, C., Hansen, B., and Zeileis, M. A.: Package "strucchange", available at: ftp://ftp.gtlib.gatech.edu/pub/CRAN/web/packages/strucchange/ strucchange.pdf (last access: 6 January 2015), 2013.
HESSD

12, 245-279, 2015

Hydrologic

calibration of paired watersheds using

a MOSUM approach

H. Ssegane et al.

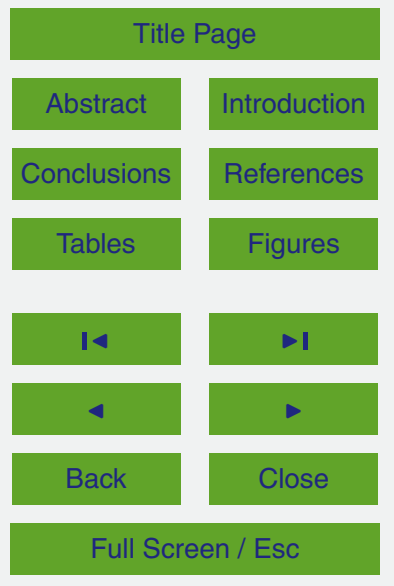

Printer-friendly Version

Interactive Discussion 
Table 1. Monthly flow and differences in water table elevation (WTE) and flow of D1 (1-3 year young pine to be intercropped with switchgrass) and D2 (14-15year pine; control watershed). The left and right columns represent months during the dormant (November to April) and growing (May to October) season, respectively. Italic rows are months with high occurrences of weir submergence (downstream weir stage above the V-notch of the weir).

\begin{tabular}{|c|c|c|c|c|c|c|c|c|c|c|c|c|}
\hline \multirow[t]{2}{*}{ Year } & \multirow[t]{2}{*}{ Month } & \multicolumn{2}{|c|}{$\begin{array}{c}\text { FLOW, } \\
\mathrm{mm}\end{array}$} & \multicolumn{2}{|c|}{$\begin{array}{c}\text { Difference, } \\
\text { [D1-D2] }\end{array}$} & \multirow{2}{*}{$\begin{array}{c}\mathrm{D} 2 \\
\text { Rain } \\
\mathrm{mm}\end{array}$} & \multirow[t]{2}{*}{ Month } & \multicolumn{2}{|c|}{$\begin{array}{l}\text { FLOW, } \\
\mathrm{mm}\end{array}$} & \multicolumn{2}{|c|}{$\begin{array}{c}\text { Difference, } \\
\text { [D1-D2] }\end{array}$} & \multirow{2}{*}{$\begin{array}{c}\text { D2 } \\
\text { Rain } \\
\text { mm }\end{array}$} \\
\hline & & D1 & $\mathrm{D} 2$ & $\begin{array}{c}\text { WTE } \\
\mathrm{cm}\end{array}$ & $\begin{array}{c}\text { FLOW } \\
\mathrm{mm}\end{array}$ & & & D1 & D2 & $\begin{array}{l}\text { WTE } \\
\mathrm{cm}\end{array}$ & $\begin{array}{c}\text { FLOW } \\
\mathrm{mm}\end{array}$ & \\
\hline \multicolumn{13}{|c|}{ Pre-harvest/Post-harvest of D1 } \\
\hline \multirow[t]{7}{*}{2009} & Nov & 89 & 90 & 27 & -1 & 209 & May & 11 & 0 & 47 & 11 & 81 \\
\hline & Dec & 77 & 53 & 27 & 24 & 180 & Jun & 0 & 0 & 66 & 0 & 100 \\
\hline & Jan & 8 & 16 & 15 & -8 & 53 & Jul & 0 & 0 & 77 & 0 & 117 \\
\hline & Feb & 3 & 12 & 16 & -10 & 69 & Aug & 39 & 14 & 58 & 25 & 244 \\
\hline & Mar & 5 & 24 & 23 & -19 & 48 & Sep & 138 & 135 & 32 & 3 & 287 \\
\hline & Apr & 18 & 22 & 42 & -4 & 88 & Oct & 12 & 8 & 27 & 4 & 75 \\
\hline & \multicolumn{11}{|c|}{ Post-harvest of D1 } & \\
\hline \multirow[t]{6}{*}{2010} & Nov & 0 & 0 & 9 & 0 & 45 & May & 0 & 0 & 17 & 0 & 33 \\
\hline & Dec & 7 & 11 & 11 & -3 & 82 & Jun & 0 & 0 & 22 & 0 & 47 \\
\hline & Jan & 96 & 139 & 17 & -43 & 177 & Jul & 0 & 0 & 26 & 0 & 111 \\
\hline & Feb & 80 & 66 & 24 & 15 & 111 & Aug & 0 & 0 & 31 & 0 & 175 \\
\hline & Mar & 42 & 41 & 15 & 1 & 138 & Sep & 42 & 49 & 21 & -7 & 421 \\
\hline & Apr & 13 & 17 & 14 & -4 & 47 & Oct & 98 & 112 & 13 & -13 & 25 \\
\hline \multirow[t]{6}{*}{2011} & Nov & 7 & 6 & 15 & 1 & 68 & May & 0 & 0 & 19 & 0 & 17 \\
\hline & Dec & 2 & 3 & 13 & -1 & 37 & Jun & 0 & 0 & 22 & 0 & 67 \\
\hline & Jan & 68 & 78 & 13 & -9 & 147 & Jul & 0 & 0 & 28 & 0 & 50 \\
\hline & Feb & 54 & 58 & 18 & -4 & 99 & Aug & 59 & 18 & 24 & 41 & 256 \\
\hline & Mar & 8 & 11 & 9 & -4 & 83 & Sep & 53 & 39 & 30 & 14 & 185 \\
\hline & Apr & 3 & 5 & 12 & -2 & 38 & Oct & 60 & 46 & 23 & 13 & 131 \\
\hline \multirow[t]{6}{*}{2012} & Nov & 0 & 1 & 12 & -1 & 20 & May & 0 & 0 & 16 & 0 & 130 \\
\hline & Dec & 52 & 45 & 14 & 7 & 159 & Jun & 1 & 1 & 19 & 1 & 52 \\
\hline & Jan & 20 & 19 & 13 & 1 & 62 & Jul & 0 & 0 & 25 & 0 & 172 \\
\hline & Feb & 11 & 12 & 10 & -1 & 65 & Aug & 62 & 68 & 25 & -6 & 318 \\
\hline & Mar & 23 & 24 & 10 & -2 & 84 & Sep & 40 & 44 & 15 & -4 & 132 \\
\hline & Apr & 11 & 11 & 10 & 1 & 96 & Oct & 2 & 1 & 10 & 1 & 110 \\
\hline
\end{tabular}

HESSD

$12,245-279,2015$

Hydrologic

calibration of paired watersheds using

a MOSUM approach

H. Ssegane et al.

Title Page

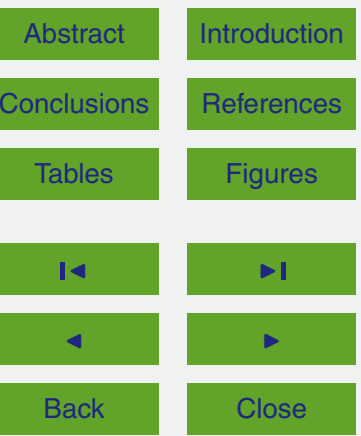

Full Screen / Esc

Printer-friendly Version

Interactive Discussion 
Table 2. Monthly differences in water table elevation (WTE) and flow of D3 (clear-cut for planting switchgrass only) and D2 (14-15 year pine; control watershed). The left and right columns represent months during the dormant (November-April) and growing (May-October) season, respectively. Italic rows are months with high occurrences of weir submergence (downstream weir stage above the V-notch of the weir) and bold rows are months when backflow (downstream weir stage greater than upstream weir stage) occurred on D3.

\begin{tabular}{|c|c|c|c|c|c|c|c|c|c|c|c|c|}
\hline \multirow[t]{2}{*}{ Year } & \multirow[t]{2}{*}{ Month } & \multicolumn{2}{|c|}{$\begin{array}{c}\text { FLOW, } \\
\mathrm{mm}\end{array}$} & \multicolumn{2}{|c|}{$\begin{array}{l}\text { Difference, } \\
\text { [D3-D2] }\end{array}$} & \multirow{2}{*}{$\begin{array}{c}\mathrm{D} 2 \\
\text { Rain } \\
\mathrm{mm}\end{array}$} & \multirow[t]{2}{*}{ Month } & \multicolumn{2}{|c|}{$\begin{array}{c}\text { FLOW, } \\
\mathrm{mm}\end{array}$} & \multicolumn{2}{|c|}{$\begin{array}{l}\text { Difference, } \\
\text { [D3-D2] }\end{array}$} & \multirow{2}{*}{$\begin{array}{c}\mathrm{D} 2 \\
\text { Rain } \\
\mathrm{mm}\end{array}$} \\
\hline & & D2 & D3 & $\begin{array}{l}\text { WTE } \\
\mathrm{cm}\end{array}$ & $\begin{array}{c}\text { FLOW } \\
\mathrm{mm}\end{array}$ & & & D2 & D3 & $\begin{array}{l}\text { WTE } \\
\mathrm{cm}\end{array}$ & $\begin{array}{c}\text { FLOW } \\
\mathrm{mm}\end{array}$ & \\
\hline \multicolumn{13}{|c|}{ Pre-harvest/Post-harvest of D3 } \\
\hline \multirow[t]{6}{*}{2009} & Nov & 90 & 86 & 15 & -4 & 209 & May & 0 & 0 & -14 & 0 & 81 \\
\hline & Dec & 53 & 51 & 23 & -2 & 180 & Jun & 0 & 0 & -19 & 0 & 100 \\
\hline & Jan & 16 & 15 & 13 & -1 & 53 & Jul & 0 & 0 & -23 & 0 & 117 \\
\hline & Feb & 12 & 12 & 15 & -1 & 69 & Aug & 14 & 13 & -24 & -1 & 244 \\
\hline & Mar & 24 & 23 & 14 & -1 & 48 & Sep & 135 & 130 & -3 & -5 & 287 \\
\hline & Apr & 22 & 21 & 12 & -1 & 88 & Oct & 8 & 8 & 4 & 0 & 75 \\
\hline \multicolumn{13}{|c|}{ Post-harvest of D3 } \\
\hline \multirow[t]{6}{*}{2010} & Nov & 0 & 0 & 14 & 0 & 45 & May & 0 & 0 & 24 & 0 & 33 \\
\hline & Dec & 11 & 8 & 14 & -3 & 82 & Jun & 0 & 0 & 19 & 0 & 47 \\
\hline & Jan & 139 & 30 & 16 & -109 & 177 & Jul & 0 & 0 & 18 & 0 & 111 \\
\hline & Feb & 66 & 26 & 18 & -40 & 111 & Aug & 0 & 0 & 16 & 0 & 175 \\
\hline & Mar & 41 & 25 & 11 & -17 & 138 & Sep & 49 & 40 & 19 & -9 & 421 \\
\hline & Apr & 17 & 16 & 11 & -1 & 47 & Oct & 112 & 94 & 16 & -17 & 25 \\
\hline \multirow[t]{6}{*}{2011} & Nov & 6 & 11 & 9 & 6 & 68 & May & 0 & 0 & 18 & 0 & 17 \\
\hline & Dec & 3 & 7 & -8 & 3 & 37 & Jun & 0 & 0 & 12 & 0 & 67 \\
\hline & Jan & 78 & 56 & 10 & -22 & 147 & Jul & 0 & 0 & 6 & 0 & 50 \\
\hline & Feb & 58 & 52 & 17 & -5 & 99 & Aug & 18 & 26 & 9 & 8 & 256 \\
\hline & Mar & 11 & 8 & 13 & -4 & 83 & Sep & 39 & 57 & 22 & 18 & 185 \\
\hline & Apr & 5 & 5 & 17 & 0 & 38 & Oct & 46 & 55 & 17 & 9 & 131 \\
\hline \multirow[t]{6}{*}{2012} & Nov & 1 & 7 & 10 & 6 & 20 & May & 0 & 3 & 17 & 3 & 130 \\
\hline & Dec & 45 & 57 & 9 & 13 & 159 & Jun & 1 & 5 & 12 & 4 & 52 \\
\hline & Jan & 19 & 17 & 8 & -2 & 62 & Jul & 0 & 0 & 5 & 0 & 172 \\
\hline & Feb & 12 & 13 & 1 & 2 & 65 & Aug & 68 & 88 & 0 & 20 & 318 \\
\hline & Mar & 24 & 27 & 4 & 3 & 84 & Sep & 44 & 47 & 8 & 3 & 132 \\
\hline & Apr & 11 & 5 & 5 & -6 & 96 & Oct & 1 & 8 & 10 & 7 & 110 \\
\hline
\end{tabular}

HESSD

$12,245-279,2015$

Hydrologic

calibration of paired watersheds using

a MOSUM approach

H. Ssegane et al.

Title Page

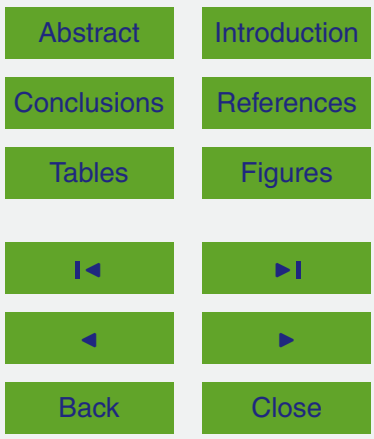

Full Screen / Esc

Printer-friendly Version

Interactive Discussion 


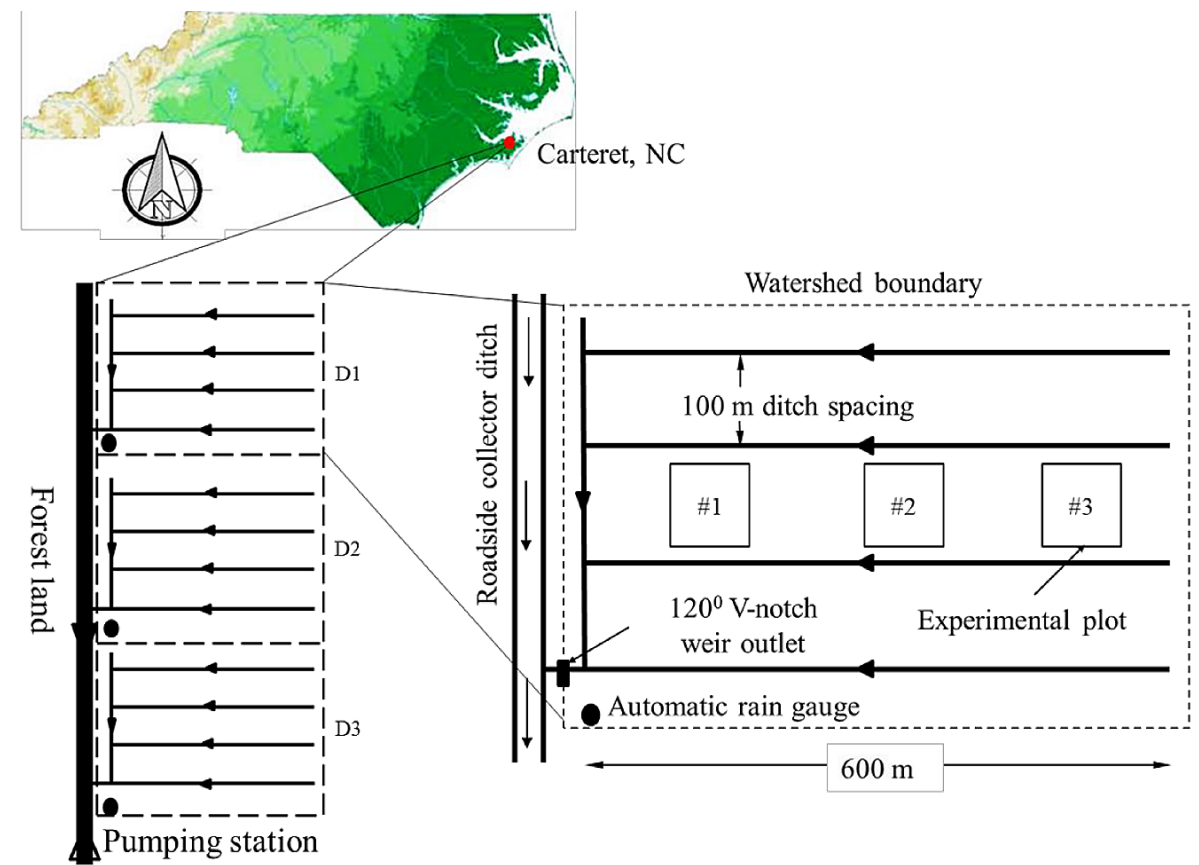

Figure 1. Location and layout of artificially drained pine-forest experimental watersheds with monitoring stations, Carteret County, North Carolina. The water table elevation (WTE) was monitored in plots \#1 and \#3.

\section{HESSD}

$12,245-279,2015$

\section{Hydrologic}

calibration of paired watersheds using a MOSUM approach

H. Ssegane et al.

Title Page

Abstract

Introduction

Conclusions

References

Tables

Figures

14

I

4

Back

Close

Printer-friendly Version

Interactive Discussion 


\begin{tabular}{|c|c|c|c|c|c|c|c|c|c|c|}
\hline \multirow{2}{*}{ WS } & \multirow{2}{*}{ Operational practice } & \multirow{2}{*}{ comments } & & 009 & \multicolumn{2}{|c|}{2010} & \multicolumn{2}{|c|}{2011} & \multicolumn{2}{|l|}{2012} \\
\hline & & & \multicolumn{8}{|c|}{ J FMAM J J A SOND J FMAM J J A SOND J FMAM J J A SOND J FMAM J J A SO } \\
\hline \multirow{3}{*}{ D0 } & Harvesting & Jan-05 to April-01 & & & & & & & & \\
\hline & Shearing \& Bedding & Jun-13 to Jul-30 & & & & & & & & \\
\hline & Pine planting & Jan- 18 to Jan- 20 & & & & & & & & \\
\hline \multirow{7}{*}{ D1 } & Harvesting & Jan-01 to April-29 & & & & & & & & \\
\hline & Shearing \& Bedding & Jun-13 to Aug-07 & & & & & & & & \\
\hline & Pine planting & Jan-18 to Jan-20 & & & & & & & & \\
\hline & Shearing between rows & Dec-16 to Dec-17 & & & & & & & & \\
\hline & Broad leaf control & Aug-11, 2011 & & & & & & & & \\
\hline & Switchgrass seeding & Aug-15, 2011 & & & & & & & & \\
\hline & Switchgrass re-seeding & Apr-09, 2012 & & & & & & & & \\
\hline D2 & Thinning & End: Jan-22, 2009 & & & & & & & & \\
\hline \multirow{6}{*}{ D3 } & $85 \%$ - Harvesting & Oct-19 to Nov-30 & & & & & & & & \\
\hline & $100 \%$ - Harvesting & May-01 to May-10 & & & & & & & & \\
\hline & Shearing and Raking & Apr-12 to Apr-19 & & & & & & & & \\
\hline & Broad leaf control & Aug-11, 2011 & & & & & & & & \\
\hline & Switchgrass seeding & Aug-15, 2011 & & & & & & & & \\
\hline & Switchgrass re-seeding & Apr-09, 2012 & & & & & & & & \\
\hline
\end{tabular}

Figure 2. Timeline of operational management practices.

\section{HESSD}

12, 245-279, 2015

\section{Hydrologic}

calibration of paired watersheds using a MOSUM approach

H. Ssegane et al.

Title Page

Abstract

Introduction

Conclusions

References

Tables

Figures

14

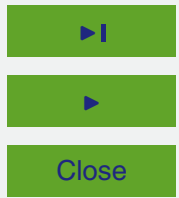

Back

Close

Full Screen / Esc

Printer-friendly Version

Interactive Discussion 


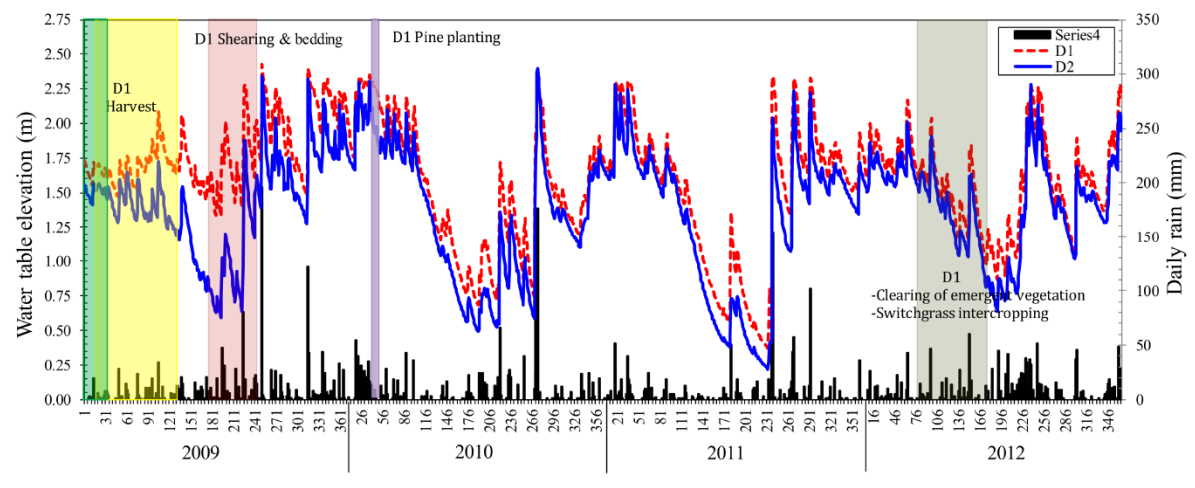

Figure 3. Daily average water table elevation (WTE) for D0 (young pine of 1-3 year old stands with natural understory) and D2 (control: pine of $14-15$ year old stands). Daily rain is average of rain on watersheds D0, D1, D2, and D3.

\section{HESSD}

$12,245-279,2015$

\section{Hydrologic}

calibration of paired watersheds using a MOSUM approach

H. Ssegane et al.

Title Page

Abstract

Introduction

Conclusions

References

Tables

Figures

14

$\rightarrow 1$

4

Back

Close

Printer-friendly Version

Interactive Discussion 


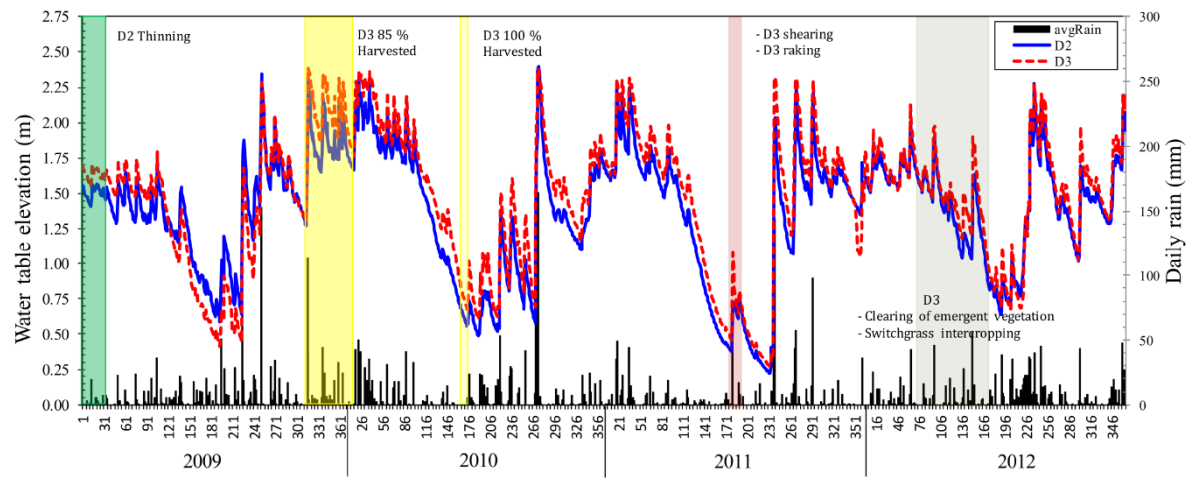

Figure 4. Daily average water table elevation (WTE) for D1 (young pine of 1-3 year old stands where spacing between pine rows were intercropped with switchgrass) and D2 (control: pine of 14-15 year old stands). Daily rain is average of rain on watersheds D0, D1, D2, and D3.

\section{HESSD}

$12,245-279,2015$

\section{Hydrologic}

calibration of paired watersheds using a MOSUM approach

H. Ssegane et al.

Title Page

14

Printer-friendly Version

Interactive Discussion 


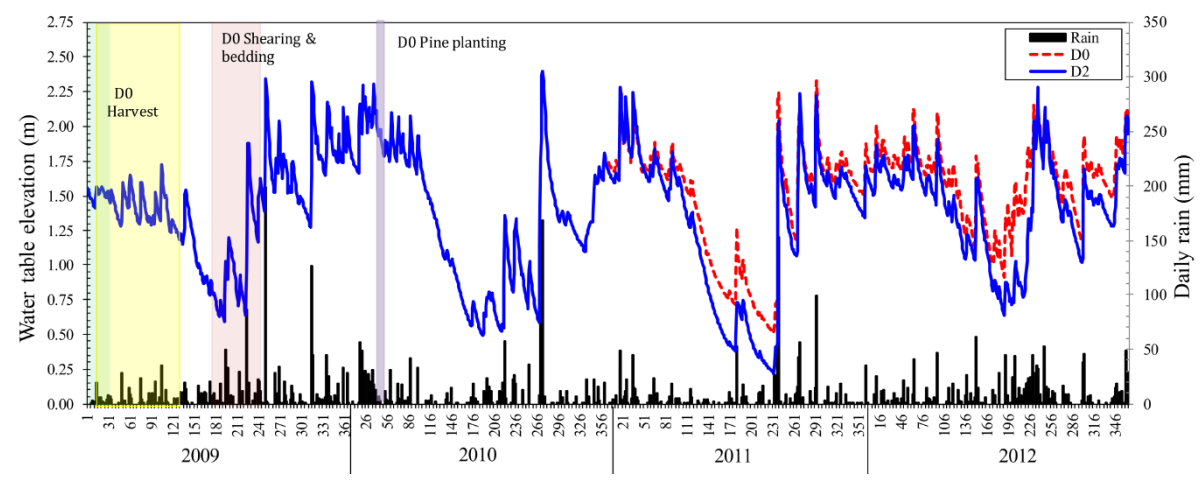

Figure 5. Daily average water table elevation (WTE) for D3 (clear-cut with emergent vegetation and planted with switchgrass only) and D2 (control: pine of 14-15 year old stands). Daily rain is average of rain on watersheds $\mathrm{D} 0, \mathrm{D} 1, \mathrm{D} 2$, and $\mathrm{D} 3$.

\section{HESSD}

$12,245-279,2015$

\section{Hydrologic}

calibration of paired watersheds using a MOSUM approach

H. Ssegane et al.

Title Page 


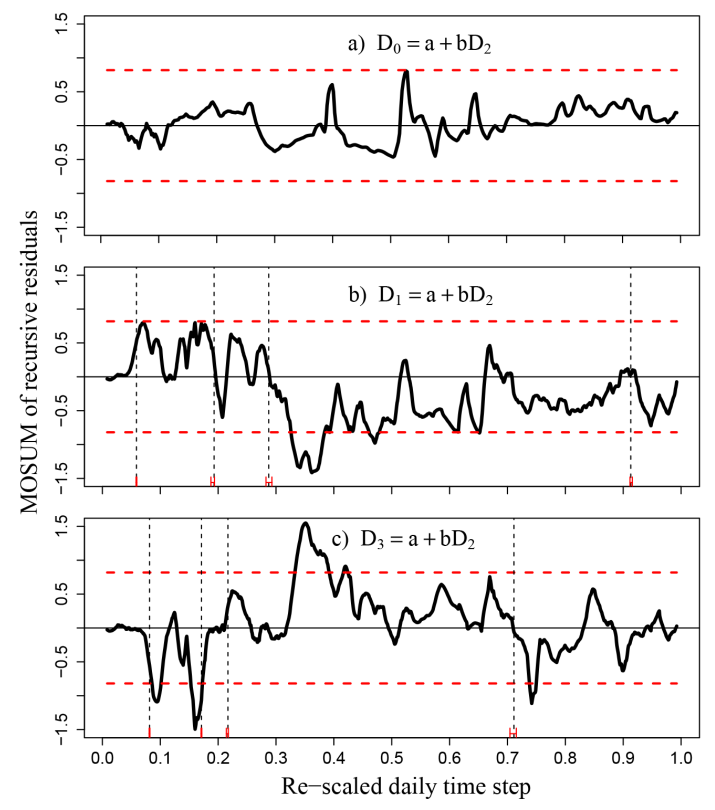

Figure 6. Graphs of the moving sums (MOSUM) of recursive residuals for the linear relationships between the water table elevation (WTE) of (a) D0 and D2, (b) D1 and D2, and (c) D3 and D2. A shift of the MOSUM outside the $95 \%$ confidence intervals (long horizontal dotted lines) is indicative of a structural break in the linear relationship. The vertical dotted lines are estimated breakpoints (break dates). The corresponding small horizontal lines that cross each break date are the respective $95 \%$ confidence intervals for each break date. Because the analysis is on moving sums, the location where the MOSUM cross the $95 \%$ confidence boundary is not always the location of the breakpoints. Also, when the MOSUM return inside the boundary, it does not mean the relationship has regained the previous structural stability. No structural break on D0-D2 but there are structural breaks on D1-D2 and D3-D2 WTE linear regression models.
HESSD

12, 245-279, 2015

Hydrologic

calibration of paired watersheds using

a MOSUM approach

H. Ssegane et al.

Title Page

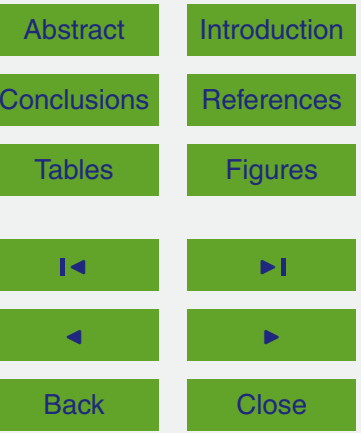

Full Screen / Esc

Printer-friendly Version

Interactive Discussion 

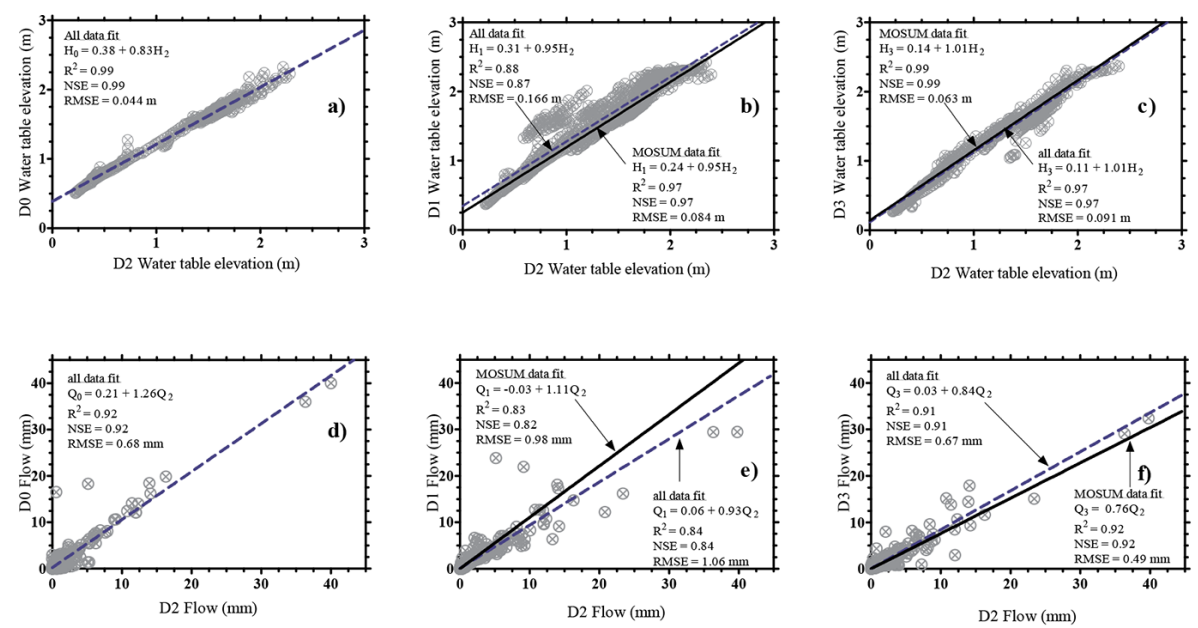

Figure 7. Calibration relationships between the daily water table elevation (WTE, a-c) and daily flow (d-f) of control (D2) and treatment (D0, D1, and D3) watersheds. All relationships are based on data period with no structural changes in the linear regression coefficients of the respective water table elevations (MOSUM data) and data from harvesting on D1 and D3 to second phase of switchgrass planting (all data).

\section{HESSD}

$12,245-279,2015$

\section{Hydrologic}

calibration of paired watersheds using a MOSUM approach

H. Ssegane et al.

Title Page

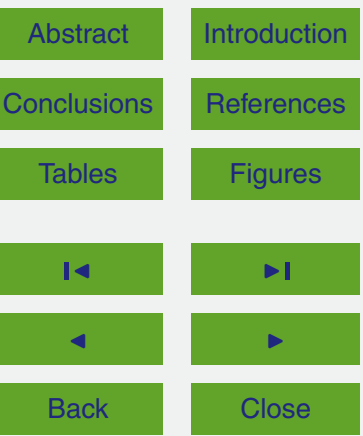

Full Screen / Esc

Printer-friendly Version

Interactive Discussion 


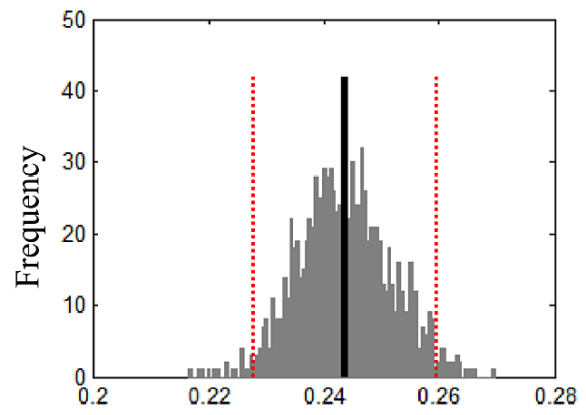

Estimated intercepts

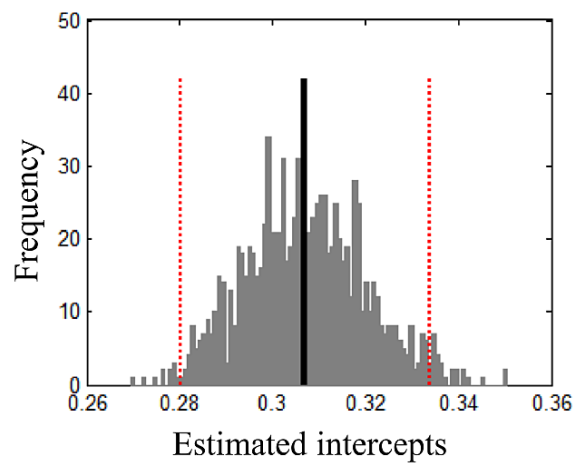

a)

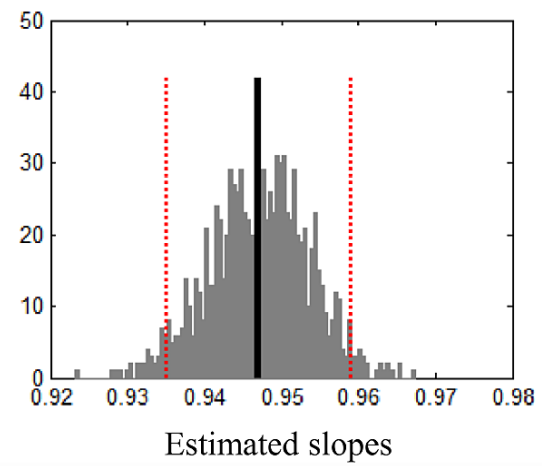

b)

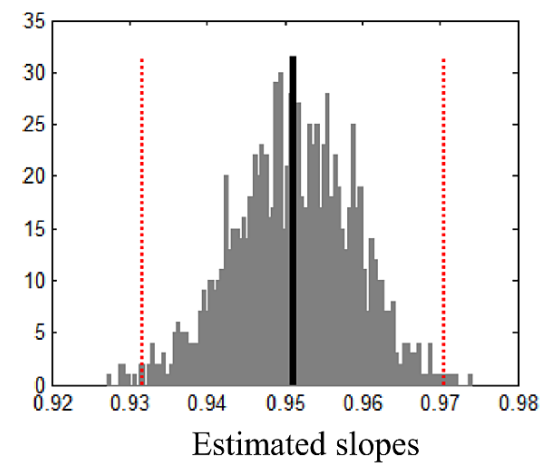

Figure 8. Uncertainty of the regression coefficients for the water table elevation (WTE) calibration equations between D1 and D2. The top graphs (a) are the intercept and slope (and corresponding $95 \%$ confidence interval; dotted vertical lines) using data only from the stable period of 1 March 2010 to 31 March 2012, as determined by moving sums of recursive residuals (MOSUM). The bottom graphs (b) are based on all data after harvesting (1 May 2009 to 31 March 2012). Distribution of coefficients is based on 1000 bootstrap resamples and a bin size of 100. The uncertainty bands of the lower plot (all data) are wider than the upper plot (MOSUM data) indicating the reduced uncertainty in regression parameters for the stable period. 